\title{
Jak2-Stat5a/b Signaling Induces Epithelial-to- Mesenchymal Transition and Stem-Like Cell Properties in Prostate Cancer
}

Pooja G. Talati, ${ }^{*}$ Lei Gu, ${ }^{*}$ Elyse M. Ellsworth, ${ }^{*}$ Melanie A. Girondo, ${ }^{*}$ Marco Trerotola, ${ }^{*}$ David T. Hoang, ${ }^{*}$ Benjamin Leiby, ${ }^{\dagger}$ Ayush Dagvadorj, ${ }^{*}$ Peter A. McCue, ${ }^{\ddagger}$ Costas D. Lallas, ${ }^{\S}$ Edouard J. Trabulsi, ${ }^{\S}$ Leonard Gomella, ${ }^{\S}$ Andrew E. Aplin, ${ }^{*}$ Lucia Languino, ${ }^{* \|}$ Alessandro Fatatis, ${ }^{* *}$ Hallgeir Rui, ${ }^{* \dagger \dagger}$ and Marja T. Nevalainen ${ }^{\star \S \| \dagger \dagger}$

From the Departments of Cancer Biology, * Pathology, ${ }^{\ddagger}$ Urology, ${ }^{\S}$ and Medical Oncology, ${ }^{\dagger \dagger}$ and the Division of Biostatistics, ${ }^{\dagger}$ Department of Pharmacology and Experimental Therapeutics, Sidney Kimmel Cancer Center, and the Department of Dermatology and Cutaneous Biology, "Thomas Jefferson University, Philadelphia; the Prostate Cancer Discovery and Development Program, "Wistar Institute, Philadelphia; and the Department of Pharmacology and Physiology, ** Drexel University College of Medicine, Philadelphia, Pennsylvania

Accepted for publication April 29, 2015.

Address correspondence to Marja T. Nevalainen, M.D. Ph.D., Department of Pathology, Medical College of Wisconsin Cancer Center, TBRC Rm C4960, 8701 Watertown Plank Rd, Milwaukee, WI 53226. E-mail: mnevalainen@mcw.edu.

\begin{abstract}
Active Stat5a/b predicts early recurrence and disease-specific death in prostate cancer (PC), which both typically are caused by development of metastatic disease. Herein, we demonstrate that Stat $5 \mathrm{a} / \mathrm{b}$ induces epithelial-to-mesenchymal transition (EMT) of PC cells, as shown by Stat5a/b regulation of EMT marker expression (Twist1, E-cadherin, $\mathrm{N}$-cadherin, vimentin, and fibronectin) in $\mathrm{PC}$ cell lines, xenograft tumors in vivo, and patient-derived PCs ex vivo using organ explant cultures. Jak2-Stat5a/b signaling induced functional end points of EMT as well, indicated by disruption of epithelial cell monolayers and increased migration and adhesion of PC cells to fibronectin. Knockdown of Twist1 suppressed Jak2-Stat5a/b-induced EMT properties of PC cells, which were rescued by re-introduction of Twist1, indicating that Twist1 mediates Stat5a/b-induced EMT in PC cells. While promoting EMT, Jak2-Stat5a/b signaling induced stemlike properties in $\mathrm{PC}$ cells, such as sphere formation and expression of cancer stem cell markers, including BMI1. Mechanistically, both Twist1 and BMI1 were critical for Stat5a/b induction of stem-like features, because genetic knockdown of Twist1 suppressed Stat5a/b-induced BMI1 expression and sphere formation in stem cell culture conditions, which were rescued by re-introduction of BMI1. By using human prolactin knock-in mice, we demonstrate that prolactin-Stat5a/b signaling promoted metastases formation of PC cells in vivo. In conclusion, our data support the concept that Jak2-Stat5a/b signaling promotes metastatic progression of PC by inducing EMT and stem cell properties in PC cells. (Am J Pathol 2015, 185: 2505-2522; http://dx.doi.org/10.1016/j.ajpath.2015.04.026)
\end{abstract}

Most prostate cancer (PC)-related deaths are because of development of metastatic disease. A central process in metastatic dissemination of $\mathrm{PC}$ is epithelial-to-mesenchymal transition (EMT), during which cancer cells attain more motile and invasive properties, invade through the basement membrane, and survive in systemic circulation. ${ }^{1-3}$ Extravasation at distant organ sites is followed by adhesion of cancer cells to extracellular matrix proteins, such as fibronectin, ${ }^{4-6}$ leading to formation of premetastatic niches and subsequent formation of macroscopic metastases. ${ }^{7-9}$

Hallmarks of EMT in PC include disruption of adherens junctions through down-regulation of E-cadherin, ${ }^{2}$ concomitant with a development of a migratory phenotype and up-regulation of mesenchymal markers, such as N-cadherin, vimentin, and fibronectin. $^{10,11}$ Loss of E-cadherin results from mutations, DNA methylation, or silencing of E-cadherin promoter

Supported by NIH/NCI grants 2RO1CA11358-06 and 1R21CA17875501 (M.T.N.), CA185918 and CA188575 (H.R.), and CA160495 (A.E.A.). Shared resources of the Sidney Kimmel Cancer Center at Thomas Jefferson University are supported by NIH Cancer Center support grant CA56036-08.

Disclosures: None declared.

Current address of M.J.N., Medical College of Wisconsin Cancer Center, Milwaukee, WI. 
regions during transcription. ${ }^{12,13}$ A predominant repressor of E-cadherin gene transcription and an inducer of $\mathrm{N}$-cadherin expression during EMT is Twist $1,{ }^{14-16}$ which belongs to the group of EMT transcription factors (Slug, Snail, Zeb1, and Zeb2). ${ }^{17}$ In addition to suppressing E-cadherin gene transcription through binding of the E-box domain of the E-cadherin promoter, ${ }^{14}$ Twist1 also enhances migration and invasion of cancer cells through other molecular mechanisms, including induction of Rac1, matrix metalloproteinase-1, and invadopodia. ${ }^{14,18-24}$ Recently, increasing evidence has linked EMT to stem cell properties, indicating that the key molecules inducing EMT may also promote a stem or progenitor cell-like phenotype with capabilities of self-renewal and increased tumorigenicity. ${ }^{25-27} \mathrm{PC}$ stem-like cells express proteins such as Oct4, Sox2, Nanog, Nestin, CD133, CD44, ${ }^{28,29}$ and $\mathrm{BMI} 1,{ }^{30}$ of which BMI1 is a member of the polycombrepressive complex and a crucial suppressor of prosenescence mediated by $\mathrm{p} 16^{\mathrm{INK} 4 \mathrm{a}}, \mathrm{p} 14^{\mathrm{ARF}}$, and $\mathrm{p} 15^{\mathrm{INK} 4 \mathrm{~b}} \cdot 31-33$ Twist 1 has been recently shown to induce BMI1 expression through a direct binding to the BMI1 promoter, ${ }^{34}$ thus linking stem-like properties of cancer cells to EMT. ${ }^{25,34-36}$

Stat5a/b is critical for PC cell viability ${ }^{37-42}$ and induces progression of PC to castrate-resistant (CR) disease. ${ }^{38,43-49}$ Two isoforms of Stat5, Stat5a and Stat5b, function both as cytoplasmic signaling proteins and nuclear transcription factors. ${ }^{50,51}$ Stat $5 \mathrm{a} / \mathrm{b}$ is activated by phosphorylation of a conserved C-terminal residue by an upstream kinase, most commonly Jak2, ${ }^{52-54}$ which leads to Stat $5 \mathrm{a} / \mathrm{b}$ dimerization, nuclear translocation, DNA binding, and regulation of gene transcription. ${ }^{55,56}$ Known key factors activating Stat5a/b in PC include prolactin (Prl), ${ }^{40,45,57}$ growth hormone, ${ }^{58}$ erythropoietin, ${ }^{59}$ and epidermal growth factor. ${ }^{60}$ In clinical $\mathrm{PC}$, the expression of active Stat $5 \mathrm{a} / \mathrm{b}$ is elevated in $>60 \%$ of PC metastases. ${ }^{40,44-46}$ The Stat5a/b gene locus undergoes amplification in approximately $30 \%$ of CR distant PC metastases, ${ }^{46}$ and active $\mathrm{Stat} 5 \mathrm{a} / \mathrm{b}$ expression in the primary tumor predicts early PC recurrence and early PC-specific death. ${ }^{43,47}$ These findings led us to hypothesize that the active Jak2-Stat5a/b pathway induces EMT of PC cells and promotes metastatic potential of PC.

Here, we demonstrate that active $S t a t 5 a / b$ promotes EMT in $\mathrm{PC}$, as indicated by $\mathrm{Stat} 5 \mathrm{a} / \mathrm{b}$-induced down-regulation of E-cadherin with simultaneous up-regulation of Twist1, N-cadherin, vimentin, and fibronectin in PC cell lines, xenograft tumors, and patient-derived clinical PCs. Active Jak2-Stat5a/b signaling promoted migration and adhesion of PC cells to fibronectin, induced phenotypic changes characteristic of EMT, and promoted metastases formation of PC cells in vivo. Further mechanistic studies demonstrated that Twist 1 is a mediator of Jak2-Stat5a/b induction of EMT in PC cells. Active Jak2Stat $5 \mathrm{a} / \mathrm{b}$ signaling induced sphere formation of $\mathrm{PC}$ cells and expression of stem-like cancer cell markers through upregulation of Twist1, simultaneously with induction of EMT markers. Collectively, this work introduces the novel concept of active Jak2-Stat5a/b signaling promoting metastatic dissemination of PC through induction of EMT and stem-like properties of PC cells.

\section{Materials and Methods}

\section{Cell Culture and Reagents}

Human PC cell lines CWR22Rv1 and DU145 (ATCC, Manassas, VA) and CWR22Pc were cultured in RPMI 1640 medium (Mediatech, Flemington, NJ) containing 10\% fetal bovine serum (FBS; Gemini, West Sacramento, CA), 50 IU/ $\mathrm{mL}$ penicillin $/ 50 \mathrm{mg} / \mathrm{mL}$ streptomycin (Mediatech), and $50 \mu \mathrm{g} /$ $\mathrm{mL}$ L-glutamine (Mediatech). CWR22Pc cells were cultured in the presence of $0.8 \mathrm{nmol} / \mathrm{L}$ dihydrotestosterone (DHT; SigmaAldrich, St. Louis, MO). Cells were maintained in a $37^{\circ} \mathrm{C}$ humidified incubator with a mixture of $95 \%$ air and $5 \% \mathrm{CO}_{2}$. All cell lines included in this study have been authenticated on a regular basis in the users' laboratory by observation of characteristic cell morphology, DNA fingerprinting, androgen responsiveness, and expression of cell line-specific markers, such as Stat5a/b, androgen receptor (AR), and prostate-specific antigen.

\section{Adenoviral Generation and Gene Delivery}

Gene delivery and expression of PrlR, wild-type (WT) Stat5a, or LacZ [negative control (Ctrl)] were conducted using adenovirus as an expression vector. pcDNA-CMV-PrlR and pcDNA-CMV-WTStat5a were cloned into an adenoviral vector using BD Adeno-XTM Expression System 2 (BD Biosciences, Palo Alto, CA), as previously described, ${ }^{38,41,44,45,61}$ and according to the manufacturer's protocol. Viral stocks of adPrlR, adWTStat5a, and adLacZ were expanded in large-scale cultures, purified by double cesium chloride gradient centrifugation, and titered side-by-side using standard plaque assay in QBI-293A cells. ${ }^{62}$

\section{Lentiviral Gene Delivery}

PC cells were infected with lentivirus expressing Ctrl-shRNA, Stat5a-shRNA, Stat5b-shRNA, AR-shRNA, Twist1-shRNA, BMI1-shRNA, shRNA-resistant BMI1 (Open Biosystems, Dharmacon, GE Healthcare, Lafayette, CO), or shRNAresistant Twist ${ }^{19,63}$ (200 to $250 \mu \mathrm{L}$ of indicated lentiviral shRNA supernatant) to induce $>80 \%$ protein knockdown or overexpression.

\section{Prl Treatment}

CWR22Pc and CWR22Rv1 cells were serum starved (16 hours) in $1 \%$ charcoal dextran-stripped FBS (Gemini), and $\mathrm{Stat} 5 \mathrm{a} / \mathrm{b}$ was activated in the cells by $10 \mathrm{nmol} / \mathrm{L}$ recombinant human Prl (National Hormone and Peptide Program, Torrance, CA). PrlR levels in DU145 cells were increased using adenovirus as an expression [multiplicity of infection (MOI), 7], and cells were serum starved (16 hours) and 
Table 1 Characteristics of AZD1480-Treated Organ Cultures Derived from Clinical Prostate Cancers

\begin{tabular}{ll}
\hline Characteristics & No. $(\%)$ \\
\hline Gleason score & \\
4 & $0(0)$ \\
5 & $0(0)$ \\
6 & $1(20.0)$ \\
7 & $3(60.0)$ \\
8 & $0(0)$ \\
9 & $1(20.0)$ \\
10 & $0(0)$ \\
Unknown & $0(0)$ \\
Clinical stage & \\
T1c & $4(80.0)$ \\
T2a & $0(0)$ \\
T2b & $0(0)$ \\
T2c & $1(20.0)$ \\
T3a & $0(0)$ \\
Metastases detected & \\
Yes & $0(0)$ \\
No & $5(100.0)$ \\
Unknown & $0(0)$ \\
\hline
\end{tabular}

The median age at radical prostatectomy was 62 (range, 52 to 67 ) years. $n=5$.

treated with $10 \mathrm{nmol} / \mathrm{L} \operatorname{Prl}$ (72 hours) to induce activation of Stat5a/b. AZD1480 ${ }^{38,64}$ (200 or $500 \mathrm{nmol} / \mathrm{L}$; AstraZeneca, Boston, MA) was added to the culture medium 1 hour before Prl treatment.

\section{Boyden Chamber Migration Assay}

PC cells were suspended to the upper chambers $\left(2.5 \times 10^{4}\right.$ cells per chamber) of the motility chamber system $(8.0-\mu \mathrm{m}$ pore size; BD Biosciences) using $100 \mu \mathrm{mol} / \mathrm{L}$ fibronectin (BD Biosciences) as the chemoattractant (0\% FBS RPMI 1640 as Ctrl), and traversed cells (16 hours) were fixed, stained (Diff-Quick Staining Set; Siemens, Munich, Germany), and counted in four separate fields from three parallel samples, as described previously. ${ }^{44,65}$

\section{Fibronectin Cell Adhesion Assay}

PC cells were plated $\left(5 \times 10^{4}\right.$ cells per well) on 96 -well plates (Linbro/Titertek; MP Biomedicals, Solon, OH) coated with 7 $\mu \mathrm{g} / \mathrm{mL}$ fibronectin (BD Biosciences) or $1 \mathrm{mg} / \mathrm{mL}$ of poly-Llysine (Ctrl; Sigma-Aldrich), incubated for 1 hour, fixed with 4\% paraformaldehyde, and stained with crystal violet. This was followed by quantification of cell adhesion by a fluorescence plate reader $(595 \mathrm{~nm}$; POLARstar OPTIMA; BMG Labtech, Ortenberg, Germany) from three parallel wells.

\section{Stem Cell Sphere Formation Assay}

PC cells were grown on low-attachment plates (Costar; SigmaAldrich), with stem cell medium (Dulbecco's modified Eagle's medium/F12; Life Technologies, Carlsbad, CA) prepared ${ }^{66-68}$ for 7 days and analyzed for total sphere number and diameter by ImageJ software (NIH, Bethesda, MD; http://imagej.nih. gov/ij).

\section{Ex Vivo Organ Explant Cultures of Clinical PCs}

PC specimens were obtained from patients (Table 1) with localized or locally advanced PC undergoing radical prostatectomy and bilateral iliac lymphadenectomy. The Thomas Jefferson University (Philadelphia, PA) Institutional Review Board found this research to be in compliance with federal regulations governing research on deidentified specimens and/ or clinical data [United States Department of Health and Human Services code 45 CFR 46.102 (f), available at $h t t p: / /$ www.hhs.gov/ohrp/humansubjects/guidance/45cfr46.html\#46. 102]. Within 1 hour of surgery, a board-certified pathologist (P.A.M.) made a selection of the tissue slices of PC nodules that were available for ex vivo organ cultures or to be frozen for other analyses. The prostate organ cultures were performed as described earlier. ${ }^{38,45,57,69-73}$ Briefly, PC tissue was cut into approximately $1-\mathrm{mm}^{3}$ pieces in a plain culture medium and transferred onto lens papers lying on stainless steel grids in petri dishes. The culture medium used was medium 199 with Earle's salts (Sigma-Aldrich) containing 10\% FBS (Quality Biological, Gaithersburg, MD), $100 \mathrm{IU} / \mathrm{mL}$ penicillin/100 mg/ $\mathrm{mL}$ streptomycin (Mediatech), and $100 \mu \mathrm{g} / \mathrm{mL}$ L-glutamine (Mediatech). The basal medium also contained $0.08 \mathrm{IU} / \mathrm{mL}$ insulin (Novo Nordisk, Princeton, NJ), $100 \mathrm{nmol} / \mathrm{L}$ dexamethasone (Sigma-Aldrich), and $100 \mathrm{nmol} / \mathrm{L}$ DHT (SigmaAldrich). Gas atmosphere was a mixture of oxygen, carbon dioxide, and nitrogen (40:5:55), and temperature was maintained at $37^{\circ} \mathrm{C}$. Twenty to thirty individual explants were cultured in a medium containing AZD1480 or vehicle at indicated concentrations for 7 days, and the medium was changed every other day.

\section{PC Xenograft Tumor Studies}

CWR22Rv1 and LNCaP cells $\left(1.0 \times 10^{7}\right)$ in $0.2 \mathrm{~mL}$ Matrigel (BD Biosciences) expressing adLacZ or adWTStat5a (MOI, 5) were inoculated s.c. into male athymic nude mice (Taconic, Germantown, NY) and sacrificed at 3 weeks.

For studies using the CWR22Pc tumor model, ${ }^{74}$ castrated male athymic nude mice (Taconic) were implanted with sustained-release DHT pellets (60-day release, one pellet per mouse; Innovative Research of America, Sarasota, FL) 3 days before PC cell inoculation. CWR22Pc cells $\left(1.5 \times 10^{7}\right)$ in $0.2 \mathrm{~mL}$ Matrigel (BD Biosciences) were inoculated s.c. into the flanks of nude mice (one tumor per mouse). AZD1480 was dissolved in $0.1 \%$ Tween 80 (SigmaAldrich)/ $0.5 \%$ methyl cellulose (K4M prep; Dow Chemical, Midland, MI). Experiments were conducted during two treatment windows: primary PC growth and castrateresistant PC growth (CRPC). In the first treatment window (primary PC growth), mice were randomly distributed into two groups (10 mice per group) with similar, average tumor 
Table 2 Antibodies Used in the Study

\begin{tabular}{llll}
\hline Antibody & Manufacturer & Dilution & Application \\
\hline E-cadherin & Biogenex & $1: 400$ & IHC (tissue) \\
Twist1 & Santa Cruz & $1: 100$ & IHC (tissue) \\
Stat5a/b & Santa Cruz & $1: 900$ & IHC (tissue) \\
Stat3 & Cell Signaling & $1: 100$ & IHC (tissue) \\
Twist1 & Santa Cruz & $1: 200$ & IFC (cell pellet) \\
BMI & Millipore & $1: 400$ & IFC (cell pellet) \\
& $\quad$ (Billerica, MD) & & \\
Stat5a/b & Santa Cruz & $1: 200$ & IHC (metastatic \\
& & & lung tissue) \\
BMI & Millipore & $1: 150$ & IHC (metastatic \\
& & & lung tissue) \\
Twist1 & Santa Cruz & $1: 400$ & IHC (metastatic \\
& & & lung tissue) \\
E-cadherin & Santa Cruz & $1: 1000$ & WB \\
N-cadherin & BD Biosciences & $1: 1000$ & WB \\
pY694 Stat5a/b & BD Biosciences & $1: 1000$ & WB \\
Stat5a/b & BD Biosciences & $1: 1000$ & WB \\
Twist1 & Santa Cruz & $1: 1000$ & WB \\
BMI1 & Millipore & $1: 1000$ & WB \\
Vimentin & Santa Cruz & $1: 1000$ & WB \\
Actin & Sigma-Aldrich & $1: 4000$ & WB \\
& $\quad$ (St. Louis, M0) & & \\
pJak2 & Millipore & $1: 1000$ & WB \\
\hline & & &
\end{tabular}

IFC, immunofluorescence cytochemistry; IHC, immunohistochemistry; WB, Western blot.

sizes when tumor volume reached 90 to $100 \mathrm{~mm}^{3}$. Starting on day 12 , mice were treated daily by oral gavage with vehicle $(0.5 \%$ methyl cellulose $)$ or AZD1480 at $30 \mathrm{mg} / \mathrm{kg}$ body weight for 21 days. Tumor sizes were measured three times weekly, and tumor volumes were calculated using the following formula: $3.14 \times$ Length $\times$ Width $\times$ Depth $/ 6$.

In the second treatment window (CRPC growth), DHT pellets were removed when the tumor volume reached approximately $400 \mathrm{~mm}^{3}$. Three days after the DHT pellet removal (on day 32), mice were randomly distributed into two groups. After DHT removal (starting at day 23), mice were treated daily with AZD1480 at $30 \mathrm{mg} / \mathrm{kg}$ or vehicle by oral gavage. Mice were sacrificed when tumor sizes reached $15 \mathrm{~mm}$ in diameter in the vehicle-treated group. Tumor growth rates were calculated from the beginning of the drug treatment. All mice were cared for according to the institutional guidelines of Thomas Jefferson University.

\section{In Vivo Metastases Assay}

DU145 cells expressing adPrlR (MOI, 5) were injected into the lateral tail veins $\left(1 \times 10^{6}\right.$ in $0.2 \mathrm{~mL} 1 \times$ phosphatebuffered saline) of WT nonobese diabetic-severe combined immunodeficiency-IL-2 receptor $\gamma$ (WT.NSG) male mice (The Jackson Laboratory, Bar Harbor, ME) and human Prl-expressing NSG (hPrl.NSG) male mice (provided by Dr. Hallgeir Rui, Thomas Jefferson University). Mice were sacrificed 8 weeks after inoculation of cells, and lungs were harvested, perfused with $1.5 \mathrm{~mL}$ of $15 \%$ India ink dye in
$3.7 \%$ formalin, and bleached in Fekete's solution $(70 \%$ ethanol, $3.7 \%$ formaldehyde, and $0.75 \mathrm{~mol} / \mathrm{L}$ glacial acetic acid). Lung surfaces were imaged, and the number of surface lung metastases was scored and quantified using ImageJ software. Paraffin-embedded lung tissue sections were immunostained for anti-Stat $5 \mathrm{a} / \mathrm{b}$, anti-BMI1, or antiTwist1 antibodies after antigen retrieval using $10 \mathrm{mmol} / \mathrm{L}$ sodium citrate buffer. Detailed antibody information is provided in Table 2.

\section{Protein Solubilization, Immunoprecipitation, Immunoblotting, and Biotinylation}

CWR22Rv1, CWR22Pc, and DU145 cell pellets were solubilized in lysis buffer with $10 \mathrm{mmol} / \mathrm{L}$ Tris- $\mathrm{HCl}(\mathrm{pH} \mathrm{7.6}), 5$ $\mathrm{mmol} / \mathrm{L}$ EDTA, $50 \mathrm{mmol} / \mathrm{L} \mathrm{NaCl}, 30 \mathrm{mmol} / \mathrm{L}$ sodium pyrophosphate, $50 \mathrm{mmol} / \mathrm{L}$ sodium fluoride, $1 \mathrm{mmol} / \mathrm{L}$ sodium orthovanadate, $1 \%$ Triton X-100, $1 \mathrm{mmol} / \mathrm{L}$ phenylmethylsulfonyl fluoride, $5 \mu \mathrm{g} / \mathrm{mL}$ aprotinin, $1 \mu \mathrm{g} / \mathrm{mL}$ pepstatin A, and $2 \mu \mathrm{g} / \mathrm{mL}$ leupeptin. ${ }^{39,41,44,75}$ Protein concentrations of clarified cell lysates were determined by simplified Bradford method (BioRad, Hercules, CA). Stat5a, Stat5b, and E-cadherin were immunoprecipitated from whole cell lysates with 4 $\mu \mathrm{L} / \mathrm{mL}$ anti-Stat5a or anti-Stat5b (Millipore, Billerica, MA) polyclonal antibodies or $4 \mu \mathrm{L} / \mathrm{mL}$ anti-E-cadherin (BD Biosciences) monoclonal antibody. Antibodies were captured by incubation for 60 minutes with protein $\mathrm{A}-$ Sepharose beads (Amersham Pharmacia Biotech, Piscataway, NJ). Primary antibodies used for immunoblotting are listed in Table 2. The immunoreaction was detected by horseradish peroxidaseconjugated goat anti-mouse or goat anti-rabbit secondary antibodies (1:2000; BD Biosciences). Immunoreactivity was detected using enhanced chemiluminescence (GE Healthcare). For cell surface E-cadherin expression, cells were grown to semiconfluence, and biotinylated with $1 \mathrm{mg} / \mathrm{mL}$ sulfoNHS-LC-biotin (Thermo Scientific, Rockford, IL) in phosphate-buffered saline for 30 minutes on ice, as described previously. ${ }^{76}$ Cells were resuspended in lysis buffer and centrifuged at $15,000 \times g$ for 20 minutes, and E-cadherin was immunoprecipitated, followed by capture of the antibodies by protein $\mathrm{A}-$ Sepharose beads and electrophoresis. Biotinylated proteins were visualized using Vectastain (Elite ABC reagent; Vector Labs, Burlingame, CA) and enhanced chemiluminescence detection reagents.

\section{Quantitative Real-Time PCR}

Total RNA was isolated using the RNeasy Mini Kit (Qiagen, Valencia, CA) and reverse transcribed with SuperScript II Reverse Transcriptase (Life Technologies). The resulting cDNAs were used for PCR using SYBR-Green Master PCR Mix (Life Technologies), and real-time quantitative PCR data collection was performed on an iCycler (BioRad). The relative expression for each target gene is expressed as $2^{-\left(C_{T}-C_{C}\right)}$, where $C_{T}$ and $C_{C}$ are the mean threshold cycle differences after normalizing to 
Table 3 PCR Primers Used in the Study

\begin{tabular}{|c|c|c|}
\hline Stem cell markers & Forward primer & Reverse primer \\
\hline Sox2 & $5^{\prime}-\mathrm{AACCCCAAGATGCACAACTC-3^{ \prime }}$ & 5'-GCTTAGCCTCGTCGATGAAC-3' \\
\hline CD44 & 5'-TTGTGGCAAATCACCAGGTA-3' & 5'-TCAGATCTGTGAACGCCTTG-3' \\
\hline Twist1 & $5^{\prime}$-AGTCTTACGAGGAGCTGCAGACG-3' & 5'-AGGAAGTCGATGTACCTGGCCG-3' \\
\hline Slug & 5'-GGGGAGAAGCCTTTTTCTTG-3' & 5'-GAGGACGTGTTGTACTCCT-3' \\
\hline Snail & $5^{\prime}$-CCTCCCTGTCAGATGAGGAC-3' & 5'-GTTCCTTATGGAGTCGGACC-3' \\
\hline Fibronectin & $5^{\prime}$-CAGTGGGAGACCTCGAGAAG- $3^{\prime}$ & $5^{\prime}$-CAAAGACTACAAGGCTCCCT-3' \\
\hline BMI1 & $5^{\prime}-$ AAATGCTGGAGAACTGGAAAG-3' & $5^{\prime}$-CGTCAGAGGAGTAGGTGTC-3' \\
\hline
\end{tabular}

glyceraldehyde-3-phosphate dehydrogenase. The cycling conditions for all PCRs were set to $95^{\circ} \mathrm{C}$ for 10 minutes, followed by 40 cycles of denaturation $\left(95^{\circ} \mathrm{C}\right.$ for 20 seconds), and annealing $\left(60^{\circ} \mathrm{C}\right.$ for 1 minute). All primers are listed in Table 3.

\section{Immunostaining of Paraffin-Embedded Tissue Sections and Cell Pellets}

Immunohistochemical staining of xenograft tumors and clinical human PCs grown as ex vivo organ cultures was performed as described previously, ${ }^{39,43,45,47,65}$ and primary antibodies used are listed in Table 2. Sections of CWR22Pc and CWR22Rv1 cell pellets, fixed with $10 \%$ formalin and paraffin embedded, were immunostained for Twist1 and BMI1 by immunofluorescence cytochemistry. Antigen retrieval was performed using Dako PT-module (Dako, Carpinteria, CA) with citric acid buffer ( $\mathrm{pH}$ 6.0) or EDTA ( $\mathrm{pH}$ 8.0) for anti-Twist1 or antiBMI1, respectively, followed by primary antibody incubation, horseradish peroxidase-conjugated anti-mouse $\operatorname{IgG}$ (Dako) secondary antibody (30 minutes), biotin tyramide (1:50; Perkin Elmer, Waltham, MA) (10 minutes), and Alexa Fluor 647 streptavidin conjugate (Life Technologies) (30 minutes). Immunofluorescence was detected by an Aperio FL slide scanner (Leica Biosystems, Buffalo Grove, IL).

\section{Scoring of Immunodetection in Paraffin-Embedded Tissue Sections}

Expression of nuclear active Stat5a/b and Stat 3 is expressed as a percentage of positively stained cells, as previously described.$^{38,71,72}$ Briefly, nuclear Stat5a/b and Stat3 protein levels were scored in a blind manner (E.M.E. and M.A.G.), and the protein levels are presented as average immunohistochemical scores from three separate views per tissue sample on a scale of 0 to 4 , where 0 indicates no expression and 4 indicates intense expression. E-cadherin, Twist1, and BMI1 expression was evaluated using the $\mathrm{H}$-score method. ${ }^{77}$ The $\mathrm{H}$-score is an assessment of both the intensity of staining and the percentage of stained cells. Briefly, the intensity of the immunostaining was scored as follows: negative (0), weak (1), moderate (2), or strong (3). Next, the percentage of cells that labeled with the specific level of intensity was calculated. The intensity score was multiplied by the percentage of cells, and the sum of these values for each level of intensity was presented as a histology score, or $\mathrm{H}$-score, ranging from 0 to 300 : $\mathrm{H}$-Score = Intensity of Immunostaining (Range, 0 to 3 ) $\times$ Percentage of Cells that Were Reactive.

\section{Statistical Analysis}

Statistical analysis for all in vitro experiments was performed using GraphPad Prism version 6.0 (GraphPad Software, La Jolla, CA), and statistical analysis of immunostained tissues was performed using SAS version 9.4 (SAS Institute, Cary, NC). For cell migration and adhesion experiments, a two-way analysis of variance was used to calculate the statistical significance between the groups, whereas cell scattering assays were analyzed by unpaired $t$ test. A linear mixed-effects model with empirical SEMs was used to determine whether levels of nuclear Stat $5 \mathrm{a} / \mathrm{b}$, cell surface E-cadherin groups, or nuclear Twist1 in the treatment groups differed from Ctrl. A random intercept term was included to account for correlation among samples from the same subject. For evaluation of the ex vivo organ explant cultures of the clinical PCs, a linear mixed-effects model with empirical SEMs was used to compare treatments. A random intercept accounted for correlation among treated cultures from the same patient. $P$ values for pairwise comparisons were adjusted using the Bonferroni method. A similar model was used for evaluation of E-cadherin and Twist1 in clinical PCs with the addition of a second random intercept term to account for correlation among the multiple views of each patient-treatment combination. For evaluation of the number of lung metastases, statistical significance was calculated using an exact Wilcoxon ranksum test. For evaluation of the levels of Stat5a/b, Twist1, and Bmi1 in the lung metastases, a linear mixed-effects model with empirical SEMs was used to compare groups at each time. Fixed effects included group, time, and group-by-time interaction. A random intercept term accounted for correlation among repeated measurements of the same sample. 
A

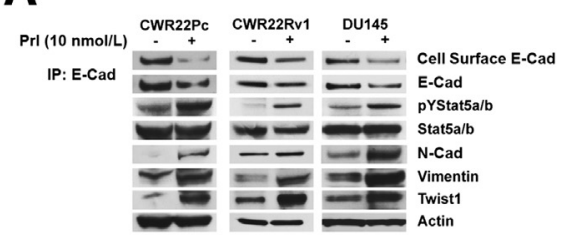

C

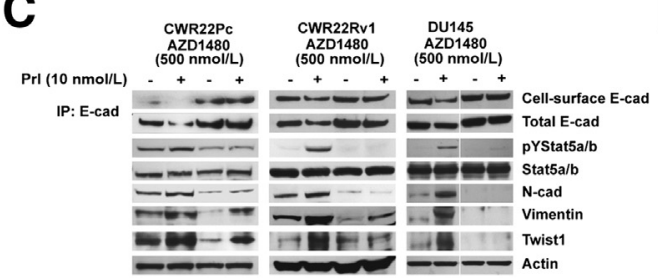

B

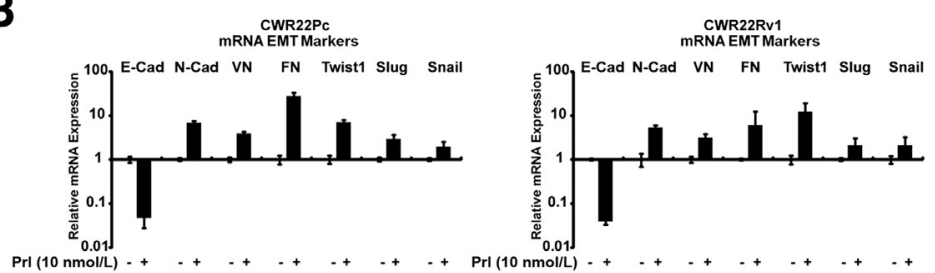

D

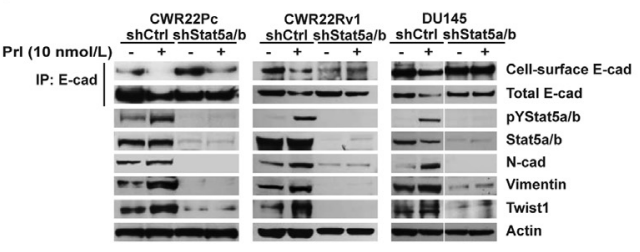

E

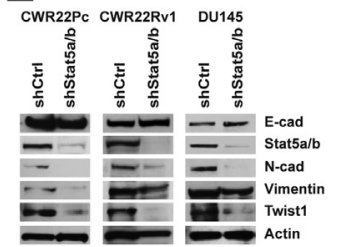

Figure 1 Active Jak2-Stat5a/b signaling induces expression of epithelial-to-mesenchymal transition (EMT) markers in prostate cancer (PC) cells in culture. A: Active Jak2-Stat5a/b signaling decreases cell surface and total E-cadherin protein expression, while up-regulating levels of $\mathrm{N}$-cadherin, vimentin, and Twist1 in PC cells. CWR22Pc, CWR22Rv1, and DU145 cells were serum starved in 1\% charcoal dextran-stripped fetal bovine serum medium (1\% CDS-FBS) for 16 hours and treated with $10 \mathrm{nmol} / \mathrm{L}$ prolactin (Prl) for 72 hours. Stat5a/b was immunoprecipitated (IP) and immunoblotted for pYStat5a/b and Stat5a/b. Whole cell lysates were immunoblotted for $\mathrm{N}$-cadherin (N-Cad), vimentin, and Twist1 with actin as the loading control. Total E-cadherin (E-Cad) and biotinylated cell surface E-cadherin were immunoprecipitated with E-cadherin monoclonal antibodies and immunoblotted for E-cadherin or streptavidin, respectively. B: Active Jak2-Stat5a/b signaling induces mRNA expression of EMT markers in PC cells. CWR22Pc and CWR22Rv1 cells were treated as described in A, and the expression of mRNA encoding E-cadherin, N-cadherin, vimentin (VN), fibronectin (FN), Twist1, Slug, and Snail was analyzed by real-time quantitative PCR. C-E: Jak2 kinase inhibitor, AZD1480, and genetic knockdown of Stat5a/b both block Prl-induced expression of EMT markers in PC cells. C: CWR22Pc, CWR22Rv1, and DU145 cells were pretreated with $500 \mathrm{nmol} / \mathrm{L}$ AZD1480 for 1 hour before stimulation with $10 \mathrm{nmol} / \mathrm{L}$ Prl for 72 hours. D: CWR22Pc, CWR22Rv1, and DU145 cells were transduced with lentiviral Stat5a/b shRNA (shStat5a/b) or scrambled control sequence (shCtrl) for 48 hours, followed by treatment with $10 \mathrm{nmol} / \mathrm{L}$ Prl for 48 hours. E: Exponentially growing CWR22Pc, CWR22Rv1, and DU145 cells were transduced with lentiviral shStat5a/b or shCtrl for 48 hours before immunoprecipitation and immunoblotting, as described in $\mathbf{A}$.

\section{Results}

\section{Jak2-Stat5a/b Signaling Induces Expression of EMT Markers in PC Cells in Vitro}

To investigate if active Jak2-Stat5a/b signaling regulates markers associated with EMT in PC, Stat5a/b signaling was activated in CWR22Pc, CWR22Rv1, and DU145 cells by treatment of the cells for 72 hours with human Prl, one of the known main activators of Stat5a/b signaling. $40,45,57,72,78,79$ Active Stat $5 \mathrm{a} / \mathrm{b}$ decreased both cell surface and total E-cadherin protein expression (Figure 1A) and mRNA levels (Figure 1B). At the same time, active Stat5a/b upregulated mesenchymal markers $\mathrm{N}$-cadherin, vimentin, and fibronectin at both mRNA and protein levels in all three cell lines (Figure 1, A and B). More important, active Stat $5 \mathrm{a} / \mathrm{b}$ associated with a marked increase in both protein and mRNA expression of Twist1 (Figure 1, A and B), a repressor of E-cadherin gene transcription and a known regulator of EMT. ${ }^{14}$ Levels of Snail and Slug mRNA were only marginally increased by Jak2-Stat $5 \mathrm{a} / \mathrm{b}$ signaling, which led us to focus further studies on Twist1 (Figure 1B). These results suggest that active Jak2-Stat5a/b signaling promotes expression of markers characteristic to EMT in PC cells.

To verify that Jak2 and Stat5a/b are critical for Prl induction of EMT in PC cells, we used pharmacological and genetic tools to disrupt Jak2 and Stat5a/b signaling. The
Jak2 kinase inhibitor, AZD1480, ${ }^{64}$ previously shown to inhibit Stat5a/b signaling in PC cells, ${ }^{38}$ suppressed Prl regulation of Jak2 phosphorylation (Supplemental Figure S1A) and E-cadherin, N-cadherin, vimentin, and Twist1 (Figure 1C). Similarly, genetic knockdown of Stat $5 \mathrm{a} / \mathrm{b}$ by lentiviral expression of $\mathrm{Stat} 5 \mathrm{a} / \mathrm{b}$ shRNA blocked Prl-induced changes in EMT marker expression (Figure 1D). At the same time, shRNA targeting Stat5a/b $(\mathrm{shStat} 5 \mathrm{a} / \mathrm{b})$ down-regulated expression of $\mathrm{N}$-cadherin, vimentin, and Twist 1 when PC cells were grown exponentially (Figure 1E). Knockdown of AR in CWR22Pc and CWR22Rv1 cells induced opposite effects to those of active Stat $5 \mathrm{a} / \mathrm{b}$ in PC cells by generally increasing the expression of $\mathrm{N}$-cadherin and Twist1, whereas E-cadherin expression remained unchanged (Supplemental Figure S1B). More important, active Stat5a/b induced EMT marker expression also in AR-negative DU145 cells, suggesting that AR is not critical for $\mathrm{Stat} 5 \mathrm{a} / \mathrm{b}$ regulation of EMT marker expression in PC. Collectively, our data indicate that both Jak2 and Stat5a/b are critical for Prl-induced expression of EMT markers in PC cells.

Jak2-Stat5a/b Signaling Induces Expression of EMTRelated Markers in Vivo in PC Xenograft Tumors and in Patient-Derived PCs ex Vivo in Organ Explant Cultures

Given that active Jak2-Stat5a/b signaling resulted in EMT marker expression in PC cells in vitro, we proceeded to 

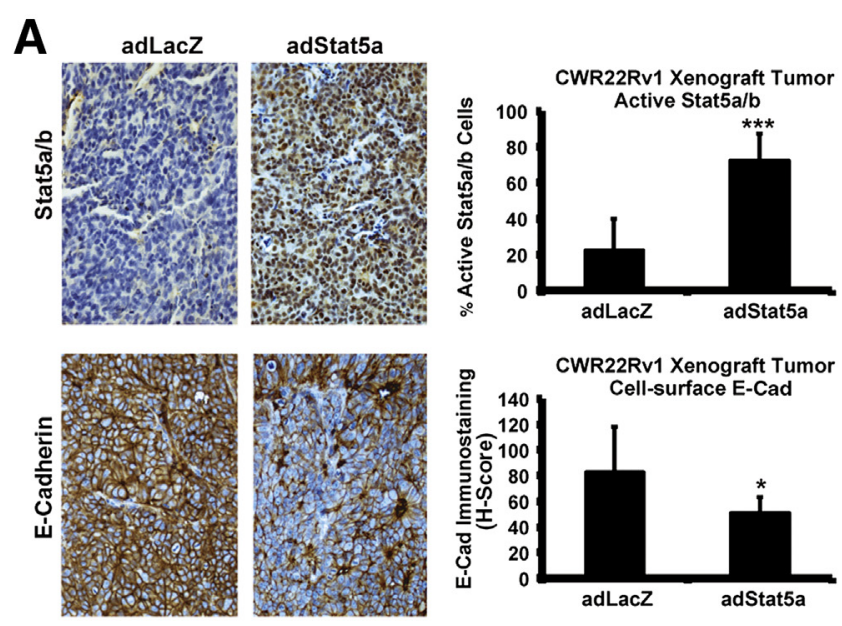

\section{B}

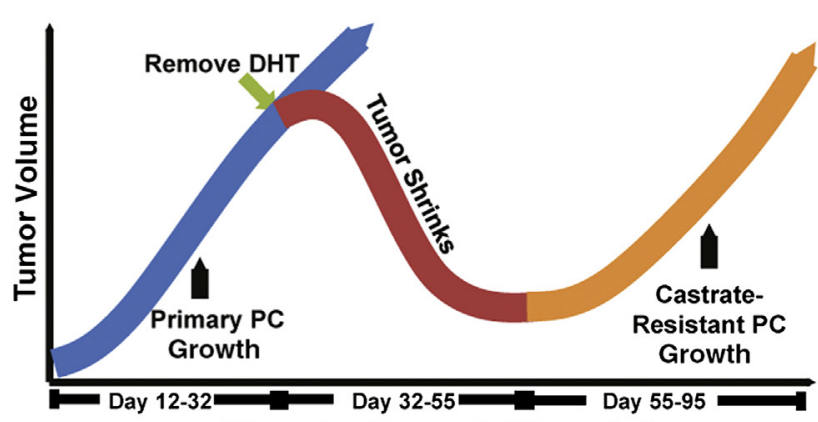

Time after Tumor Cell Inoculation
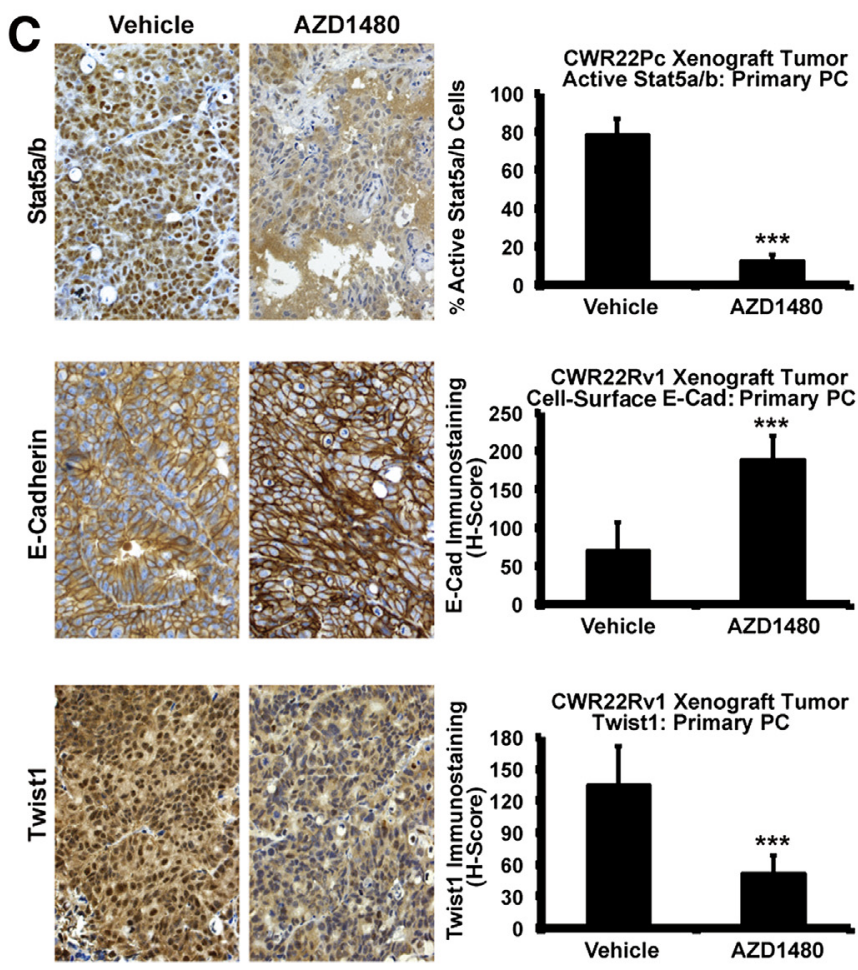

evaluate if active Stat5a/b is capable of inducing EMT markers in PC in vivo. CWR22Rv1 (Figure 2A) and LNCaP cells (Supplemental Figure S2), overexpressing Stat5a/b by adenoviral gene transduction (adWTStat5a; MOI, 5), were
Figure 2 Active Jak2-Stat5a/b signaling induces expression of epithelial-to-mesenchymal transition (EMT) markers in vivo in prostate cancer (PC) xenograft tumors. A: Active Stat5a/b signaling decreases cell surface E-cadherin in PC xenograft tumors. CWR22Rv1 cells were infected with adenovirus expressing LacZ (adLacZ) or wild-type (WT) Stat5a (adWTStat5a; multiplicity of infection, 5) and inoculated s.c. into the flanks of nude mice after 24 hours. After 3 weeks, cell surface E-cadherin and nuclear Stat5a/b levels were analyzed by immunohistochemistry (IHC) in paraffin-embedded tissue sections. B: AZD1480 increased expression of E-cadherin (E-Cad) $(P<0.001)$ while decreasing Twist1 levels $(P<0.001)$ in both primary and castrate-resistant (CR) CWR22Pc tumors. C: Active nuclear Stat5a/b, cell surface E-cadherin, and nuclear Twist1 were analyzed by IHC in CWR22Pc tumors treated with AZD1480 at $30 \mathrm{mg} /$ $\mathrm{kg}$ for 21 days, starting on day 12 (primary PC growth). On day 32, at the onset of androgen deprivation, $30 \mathrm{mg} / \mathrm{kg} \mathrm{AZD1480} \mathrm{treatment}$ continued for 95 days. Statistical significance was calculated using a linear mixed-effects model with empirical SEMs. ${ }^{*} P<0.05$, $* * * P<0.001$. DHT, dihydrotestosterone.
Vehicle
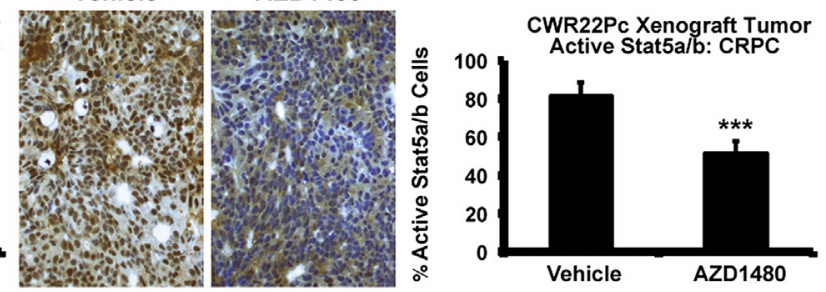
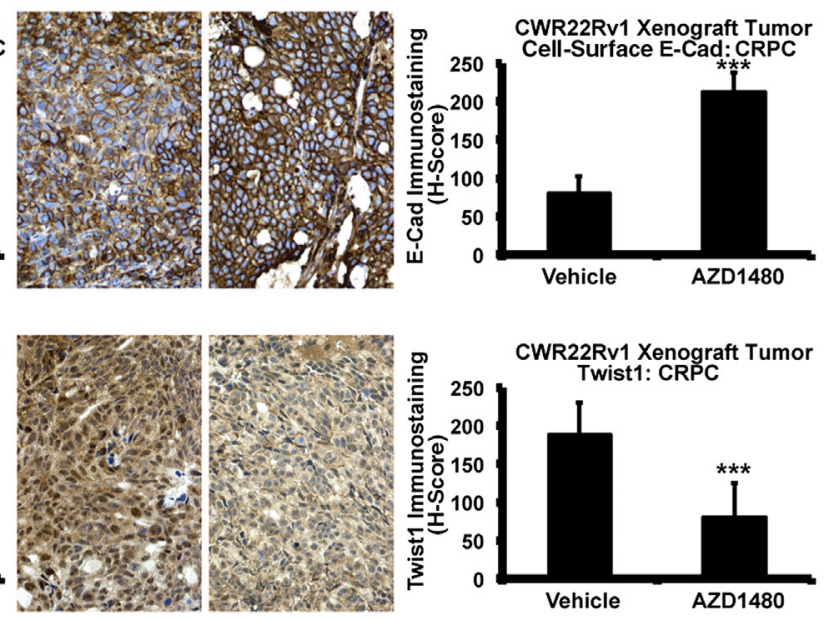

grown as s.c. xenograft tumors in nude mice to determine the impact of increased Stat5a/b signaling in PC xenografts. Immunostaining of Stat5a/b indicated high levels of active nuclear Stat5a/b expression in the tumor tissues versus Ctrl, 
A
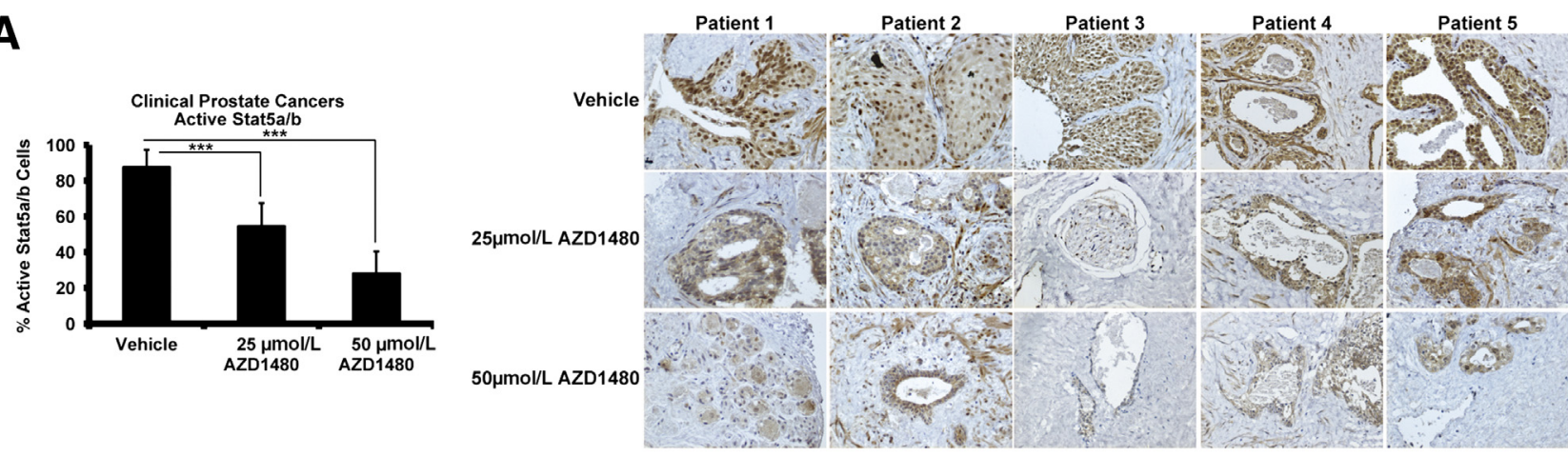

B
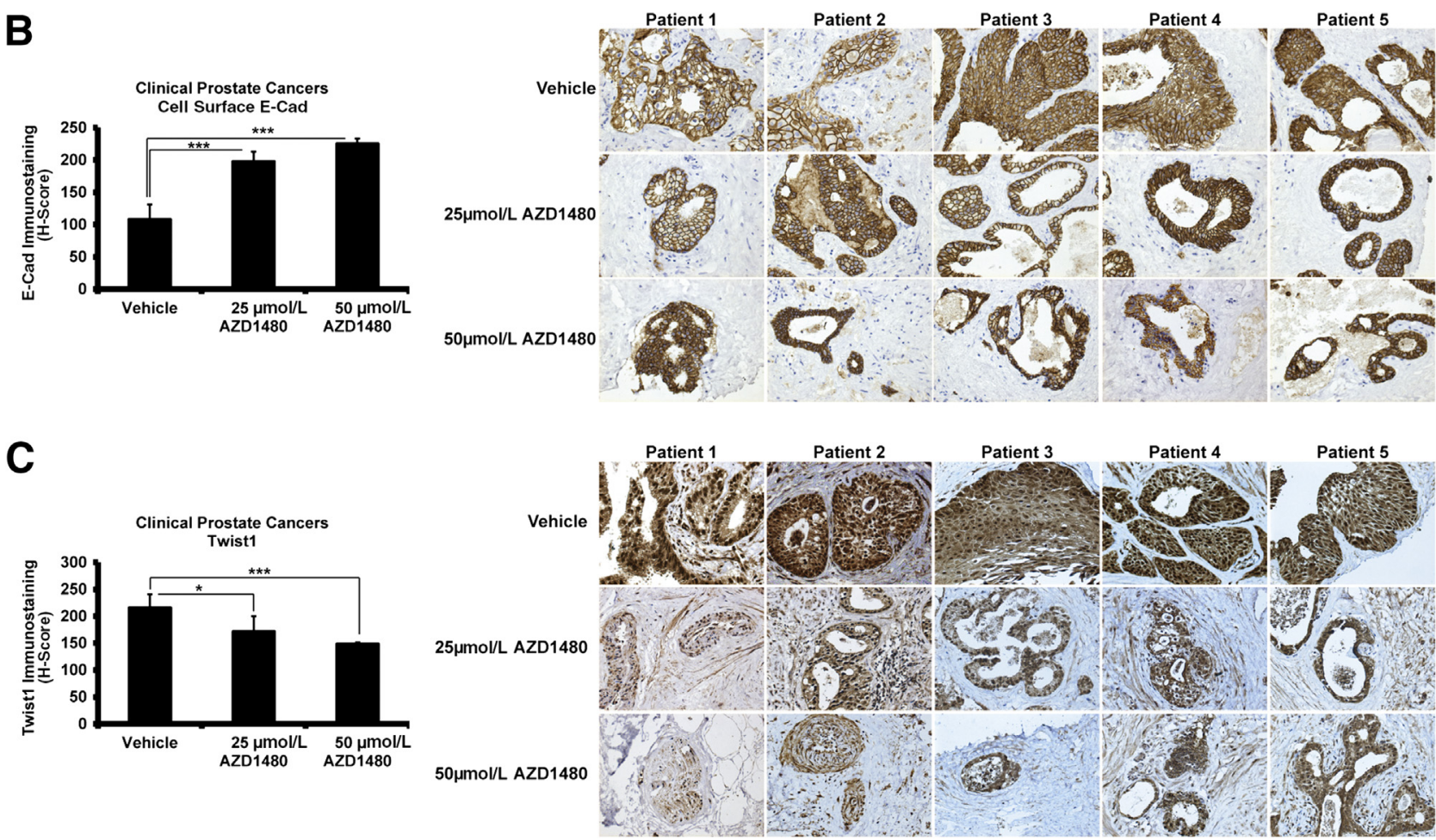

Figure 3 Active Jak2-Stat5a/b signaling induces epithelial-to-mesenchymal transition marker expression in clinical prostate cancers (PCs) ex vivo in organ explant cultures. A-C: Five patient-derived PCs (Table 1) were cultured ex vivo in explant organ cultures for 7 days in the presence of AZD1480 versus vehicle. AZD1480 decreases nuclear Stat5a/b immunostaining (A) in a dose-dependent manner, whereas it increases cell surface E-cadherin (E-Cad) expression (B) and decreases Twist1 expression (C) in clinical PCs. Statistical significance was calculated using a linear mixed-effects model with empirical SEMs. ${ }^{*} P<0.05,{ }^{* * * P}<0.001$.

as expected. More important, compared with Ctrl, increased Stat5a/b signaling $(P<0.001)$ coincided with a loss of cell surface E-cadherin expression in both CWR22Rv1 $(P<0.05)$ (Figure 2A) and $\operatorname{LNCaP}(P<0.001)$ (Supplemental Figure S2) tumors. Conversely, to test if inhibition of Stat5a/b activity suppresses EMT marker expression in vivo, we used the CWR22Pc cell line/tumor model,${ }^{74}$ which mimics the clinical course of PC in patients when grown as xenograft tumors in nude mice. ${ }^{38,74}$ Specifically, CWR22Pc cells form androgen-dependent primary PC tumors in the presence of circulating androgens, which regress on androgen deprivation and eventually recur as CRPC. ${ }^{74}$ CWR22Pc cells were inoculated s.c. into castrated nude mice supplied with androgen pellets to normalize circulating androgen levels, which were removed on day 32 .
This led to tumor regression, followed by tumor recurrence, marking the onset of CRPC. To test if Stat5a/b inhibition affects EMT marker expression during both primary growth in the presence of androgens (days 12 to 32) and CRPC growth (days 55 to 95) (Figure 2B), mice were treated with $30 \mathrm{mg} / \mathrm{kg}$ AZD1480 or vehicle during those time periods. During both primary and CR recurrent growth of CWR22Pc tumors, inhibition of Stat5a/b by AZD1480 up-regulated E-cadherin expression $(P<0.001)$, whereas levels of Twist 1 protein were down-regulated $(P<0.001)$ (Figure 2C).

To investigate if Stat5a/b signaling induces EMT in clinical PCs, we exploited the organ explant culture system of patient-derived PCs ex vivo, which we have previously described. ${ }^{38,45,57,69-73}$ All tissue components of PC, including epithelium and stroma, are retained in this culture 
A
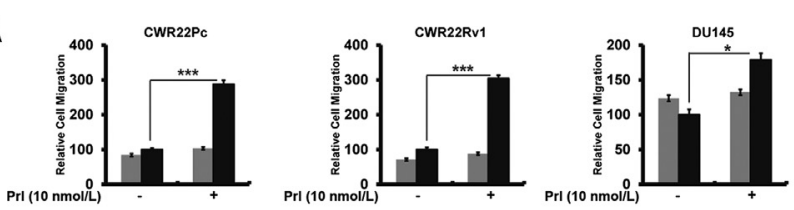

B
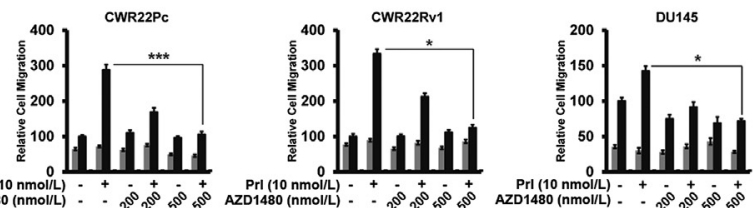

C
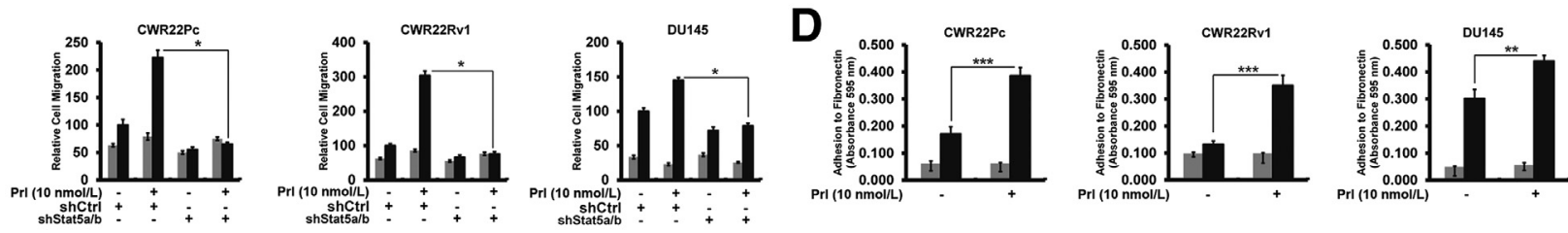

$\mathbf{E}$
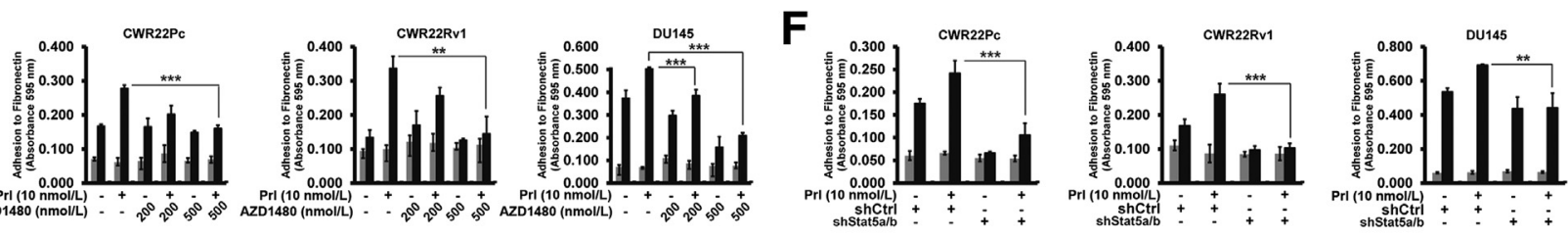

Ctrl a Fibronectin
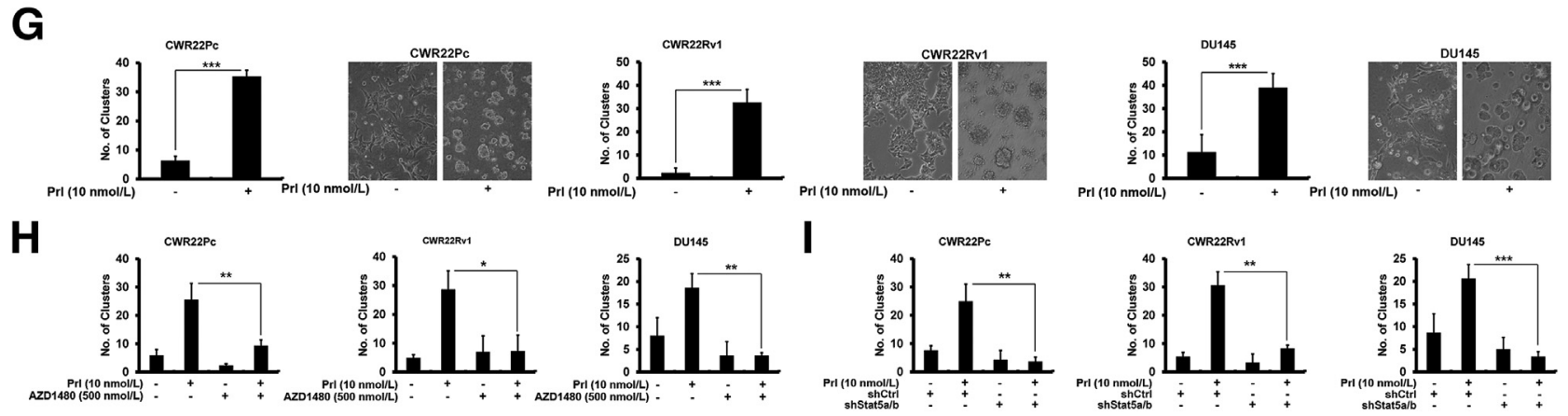

Figure 4 Jak2-Stat5a/b signaling promotes functional characteristics of epithelial-to-mesenchymal transition in prostate cancer (PC) cells. A-C: Active Jak2Stat5a/b signaling induces migration of PC cells to fibronectin. CWR22Pc, CWR22Rv1, and DU145 cells were serum starved for 16 hours, treated with $10 \mathrm{nmol} / \mathrm{L}$ prolactin (Prl) for 72 hours (A), or pretreated with AZD1480 at indicated concentrations for 1 hour (B) before treatment of the cells with $10 \mathrm{nmol} / \mathrm{L}$ Prl for 72 hours and resuspension into Boyden chambers using $100 \mu \mathrm{mol} / \mathrm{L}$ fibronectin as the chemoattractant versus control (Ctrl; $0 \%$ fetal bovine serum medium). Traversed cells were counted after 16 hours. C: CWR22Pc, CWR22Rv1, and DU145 cells were transduced with lentiviral shRNA targeting control (shCtrl) or Stat5a/b (shStat5a/b) for 48 hours, serum starved, and treated with $10 \mathrm{nmol} / \mathrm{L}$ Prl before resuspension into motility chambers. D-F: Active Jak2-Stat5a/b signaling induces adhesion of PC cells to fibronectin. D: CWR22Pc, CWR22Rv1, and DU145 cells, treated as described in A, were analyzed for adherence to $7 \mu \mathrm{g} / \mathrm{mL}$ fibronectin or $1 \mathrm{mg} / \mathrm{mL}$ poly-Llysine. E: Serum-starved CWR22Pc, CWR22Rv1, and DU145 cells were treated with AZD1480 at indicated concentrations 1 hour before $10 \mathrm{nmol} / \mathrm{L}$ Prl treatment for 48 hours before analysis for adherence to fibronectin. F: CWR22Pc, CWR22Rv1, and DU145 cells were first infected with shStat5a/b or shCtrl and treated with $10 \mathrm{nmol} / \mathrm{L}$ Prl for 48 hours in serum-starved conditions before PC cell adhesion analysis. G-I: Activation of Jak2-Stat5a/b pathway disrupts PC epithelial cell monolayers. The graphs show the numbers of scattered cell clusters. CWR22Pc, CWR22Rv1, and DU145 cells were treated as described in A and resuspended on Matrigel for 48 hours (G), with or without pretreatment with $500 \mathrm{nmol} / \mathrm{L}$ AZD1480 (H). I: CWR22Pc, CWR22Rv1, and DU145 cells were transduced with lentiviral shCtrl or shStat5a/b for 24 hours before resuspension on Matrigel in the presence or absence of $10 \mathrm{nmol} / \mathrm{L}$ Prl for 48 hours. Statistical significance was calculated by two-way analysis of variance $(\mathbf{A}-\mathbf{F})$ and unpaired $t$-test $(\mathbf{G}-\mathbf{I}) .{ }^{*} P<0.05,{ }^{* *} P<0.01$, and ${ }^{* * *} P<0.001$.

system, thus offering a more physiological model of PC growth than PC cell lines. To determine responsiveness of clinical PCs to pharmacological inhibition of Stat5a/b, PC explants from five patients (Table 1) were cultured for 7 days in the presence of AZD1480 or vehicle at the indicated concentrations (Figure 3). As expected, AZD1480 suppressed Stat5a/b activation in all five clinical PCs, as shown by a decrease in active nuclear $S t a t 5 \mathrm{a} / \mathrm{b}$ by immunohistochemistry $(P<0.001)$ (Figure 3A), but not Stat3 (Supplemental Figure S3). At the same time, AZD1480 increased E-cadherin levels in all five PCs $(P<0.001)$ (Figure 3B) in a dose-dependent manner, whereas Twist1 levels were simultaneously decreased $(P<0.001)$ (Figure $3 \mathrm{C}$ ). In summary, these data suggest that active
Stat5a/b signaling promotes expression of EMT markers in PC xenograft tumors in nude mice and in clinical patientderived PCs ex vivo.

\section{Jak2-Stat5a/b Signaling Disrupts Epithelial Cell Monolayer of PC Cells and Induces Migration and Adhesion of PC Cells to Fibronectin}

Having established that Jak2-Stat5a/b signaling induces molecular changes associated with EMT in PC in vitro and in vivo, we evaluated if Jak2-Stat5a/b signaling promotes functional end points associated with EMT in PC cells. By using a Boyden chamber assay, we tested if active Stat5a/b induces migration and adhesion of PC cells to fibronectin, 
A

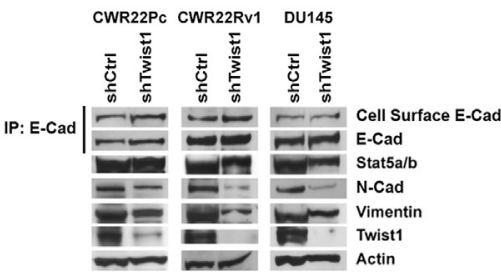

B

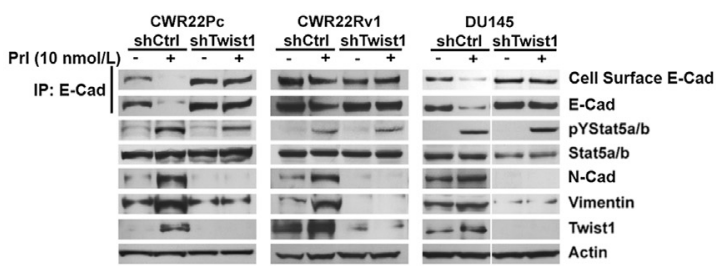

C

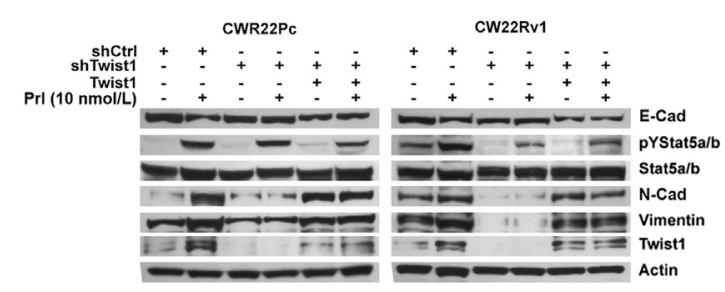

D
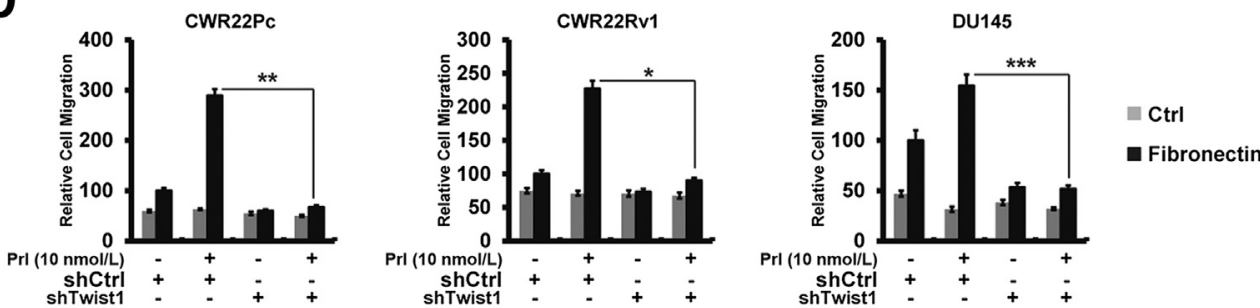

E
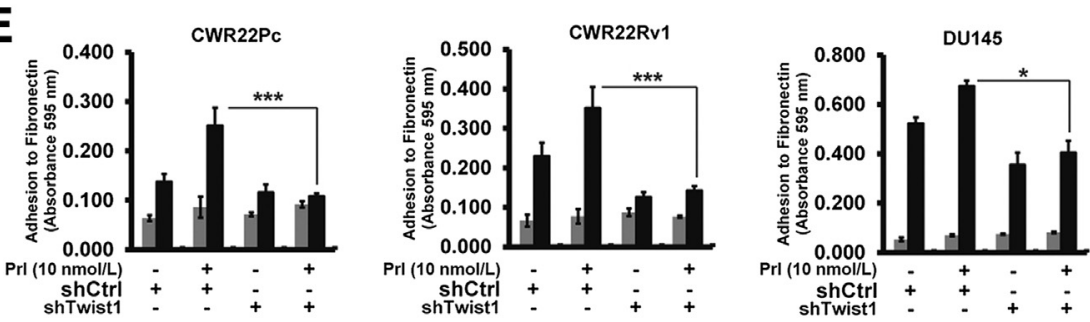

Ctrl

- Fibronectin

$\mathbf{F}$
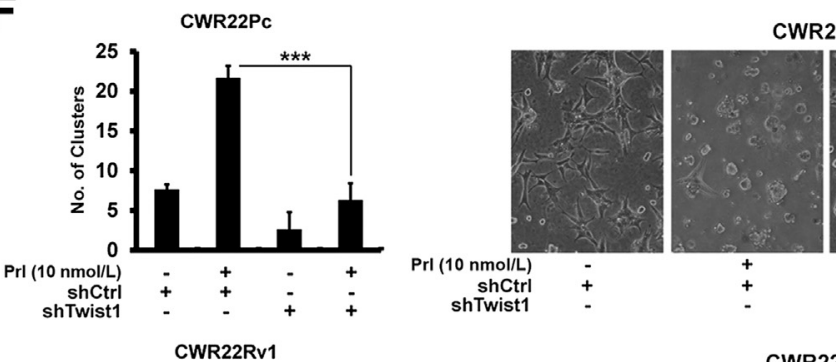

WR22Pc
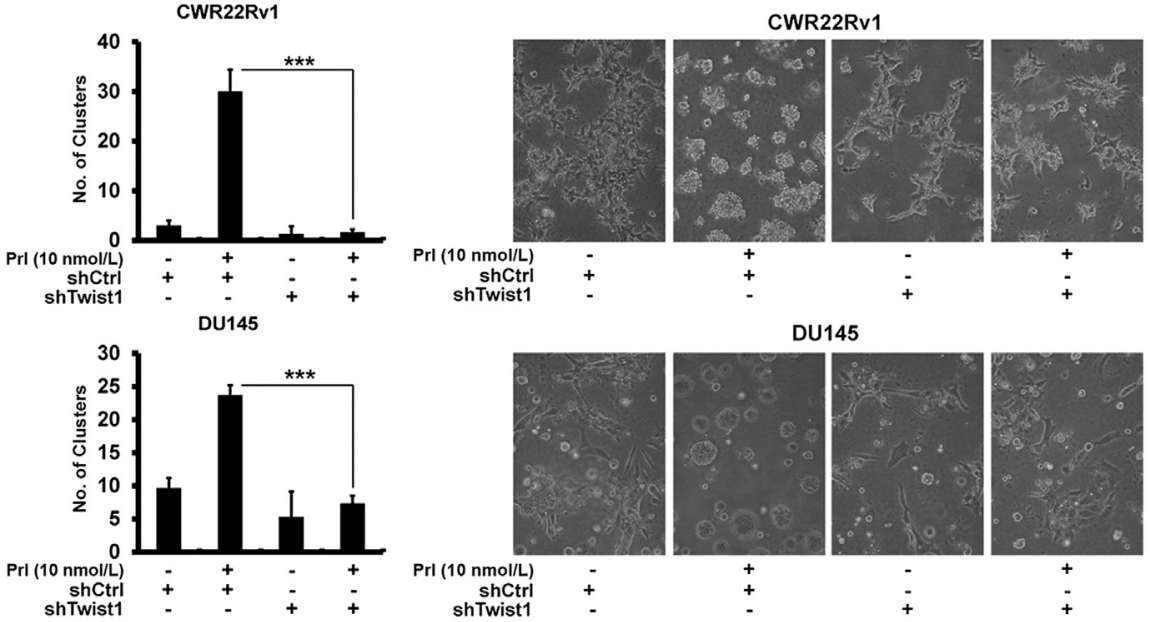

U145
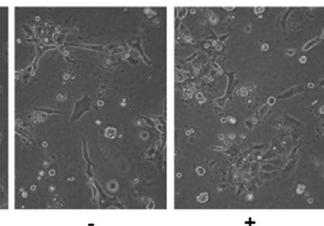
one of the key extracellular matrix components in premetastatic niches. ${ }^{4-7}$ Prl-activated Jak2-Stat5a/b increased migration of CWR22Pc, CWR22Rv1, and DU145 cells to fibronectin versus $C$ trl by 2.9 -fold $(P<0.001), 3.0$-fold $(P<0.001)$, and 1.8 -fold $(P<0.05)$, respectively (Figure 4A), which was suppressed by AZD1480 $(P<0.05)$ (Figure 4B), indicating a critical role for Jak2 in Prl-induced PC cell motility. To examine if Stat5a/b also is required for Prl-Jak2-induced PC cell migration, we knocked down $\mathrm{Stat} 5 \mathrm{a} / \mathrm{b}$ by $\operatorname{shStat} 5 \mathrm{a} / \mathrm{b}$, which led to suppression of PC cell migration $(P<0.05)$ (Figure $4 \mathrm{C})$. Because fibronectin is known to provide a habitat for adhesion and docking of circulating cancer cells in premetastatic niches, ${ }^{4,8}$ we next tested if active Stat5a/b signaling promotes adhesion of PC cells to fibronectin versus Ctrl. Active Jak2-Stat5a/b signaling led to 2.3 -fold $(P<0.001)$, 2.7-fold $(P<0.001)$, and 1.5-fold $(P<0.01)$ increases in binding of CWR22Pc, CWR22Rv1, and DU145 cells, respectively, to fibronectin (Figure 4D), which was suppressed by AZD1480 $(P<0.01)$ (Figure 4E) or shStat5a/b $(P<0.01)$ (Figure 4F).

To investigate if active Jak2-Stat5a/b signaling affects homotypic adhesion of PC cells, CWR22Pc, CWR22Rv1, and DU145 cells were grown on Matrigel (BD Biosciences). Active Jak2-Stat5a/b disrupted growth of PC cells as monolayers and promoted ability of PC cells to detach and survive in Matrigel as scattered cell clusters $(P<0.001)$ (Figure 4G). AZD1480 $(P<0.05)$ (Figure $4 \mathrm{H})$ or shStat5a/b $(P<0.01)$ (Figure $4 \mathrm{I}$ ) both suppressed PC cell scattering and restored the epithelial cell monolayer (Supplemental Figures S4 and S5). Efficient Stat5a/b knockdown by lentiviral Stat5a/b shRNA was observed in all three cell lines at 72 hours (Supplemental Figure S6). In conclusion, Jak2-Stat5a/b signaling not only increased expression of markers associated with EMT in PC cells, but also disrupted PC cell epithelial monolayer and promoted migration and adhesion of PC cells to fibronectin, functional changes consistent with induction of EMT.

\section{Twist1 Is a Mediator of Stat5a/b Induction of EMT-Associated Changes in PC}

Because expression of Twist1 was markedly increased by active Jak2-Stat5a/b signaling in PC cells, in vitro and in vivo, we investigated the involvement of Twist 1 in $S t a t 5 a / b$ induction of EMT in PC. Knockdown of Twist1 by shRNA (shTwist1) resulted in down-regulation of $\mathrm{N}$-cadherin and vimentin in exponentially growing PC cells (Figure 5A). Next, we suppressed Twist1 by shTwist 1 during Prl treatment of PC cells, which blocked Prl-Jak2-Stat5a/b induction of EMT marker expression (increased N-cadherin, increased vimentin, and decreased E-cadherin) (Figure 5B). Expression of all EMT markers was rescued by lentiviral expression of ectopic shRNA-resistant Twist1 (Figure 5C). Furthermore, Twist1 knockdown by shTwist1 suppressed migration $(P<0.05)$ (Figure 5D) and adhesion $(P<0.05)$ of $P C$ cells to fibronectin (Figure 5E) induced by active Jak2-Stat5a/b signaling in CWR22Pc, CWR22Rv1, and DU145 cells, and prevented dispersion of $\mathrm{PC}$ cells while restoring the growth of the cells as monolayers $(P<0.001)$ (Figure 5F). Collectively, these results indicate that Twist1 is required for Jak2Stat5a/b induction of EMT in PC cells.

\section{Jak2-Stat5a/b Signaling Promotes Cancer Stem-Like Properties in PC Cells}

Stat5a/b induced anchorage-independent survival of small PC cell clusters when grown on Matrigel, an observation that raised the question that Jak2-Stat5a/b signaling may induce cancer stem-like properties in PC cells. To test this, CWR22Pc and CWR22Rv1 cells were grown on lowadherence plates in stem cell culture medium and treated with Prl. Prl activation of Stat5a/b signaling led to an increase in mRNA levels of cancer stem-like cell markers (BMI, CD44, and Sox2) in 7 days. Unexpectedly, the increase in the expression of cancer stem-like cell markers induced by $\mathrm{Prl}$ was associated with simultaneous induction of EMT markers (decreased E-cadherin, increased $\mathrm{N}$-cadherin, and increased Twist1) (Figure 6A). At the same time, PC cells formed large spheres when cultured in stem cell culture conditions in the presence of Prl (Figure 6B). Prl promotion of PC cell sphere formation was suppressed by lentiviral delivery of shStat5a/b, indicating that $\mathrm{Stat} 5 \mathrm{a} / \mathrm{b}$ is critical for Prl-induced stem-like properties in PC cells (Figure 6C).

Having established that BMI1 mRNA expression was increased by Stat5a/b in PC cells and, at the same time,

\footnotetext{
Figure 5 Twist1 is a mediator of Stat5a/b induction of epithelial-to-mesenchymal transition (EMT) in prostate cancer (PC) cells. A-C: Genetic knockdown of Twist1 suppresses active Stat5a/b-induced EMT marker expression, which is restored by re-introduction of shRNA-resistant Twist1. A: Exponentially growing CWR22Pc, CWR22Rv1, and DU145 cells were transduced with lentiviral shRNA targeting Twist1 (shTwist1) for 48 hours. Total E-cadherin (E-Cad) and biotinylated cell surface E-cadherin were immunoprecipitated (IP) with E-cadherin monoclonal antibodies and immunoblotted for E-cadherin or streptavidin, respectively. Stat5a/b was immunoprecipitated and immunoblotted with anti-Stat5a/b in DU145 cells. Whole cell extracts were analyzed for N-cadherin (N-Cad), vimentin, and Twist1 expression, with actin as the loading control. B: CWR22Pc, CWR22Rv1, and DU145 cells were transduced with lentiviral shRNA targeting control (shCtrl) or shTwist1 for 48 hours, followed by treatment with $10 \mathrm{nmol} / \mathrm{L}$ prolactin (Prl) for 72 hours in serum-starved conditions. C: shRNA-resistant Twist1 was introduced using lentivirus into CWR22Pc and CWR22Rv1 cells 48 hours after the initiation of genetic Twist1 knockdown by (shTwist1) lentivirus. PC cells were serum starved for 16 hours after introduction of shRNA-resistant Twist1 and treated with $10 \mathrm{nmol} / \mathrm{L}$ Prl for 48 hours. D-F: shTwist1 suppresses adhesion and migration of PC cells to fibronectin and restores epithelial cell monolayers disrupted by active Jak2-Stat5a/b signaling. CWR22Pc, CWR22Rv1, and DU145 cells were treated as described in $\mathbf{B}$, and an equal number of cells was resuspended into motility chambers (D) or fibronectin-coated plates (E). The graphs depict the number of cells able to cross the membrane after 16 hours (D) or adherence of PC cells to fibronectin after 1 hour (E). F: The number of scattered cell clusters of CWR22Pc, CWR22Rv1, and DU145 cells was treated as in B and resuspended on Matrigel for 48 hours in the presence or absence of $10 \mathrm{nmol} / \mathrm{L} \mathrm{Prl}$. Statistical significance was calculated by two-way analysis of variance $(\mathbf{D}$ and $\mathbf{E})$ and unpaired $t$-test $(\mathbf{G}-\mathbf{I})$. ${ }^{*} P<0.05,{ }^{*} P<0.01$, and ${ }^{* * *} P<0.001$.
} 
A
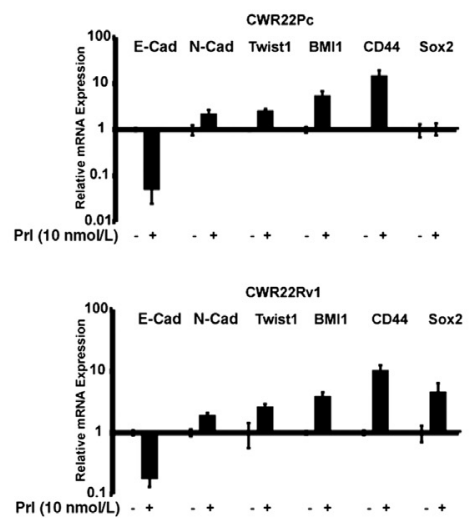

\section{C}

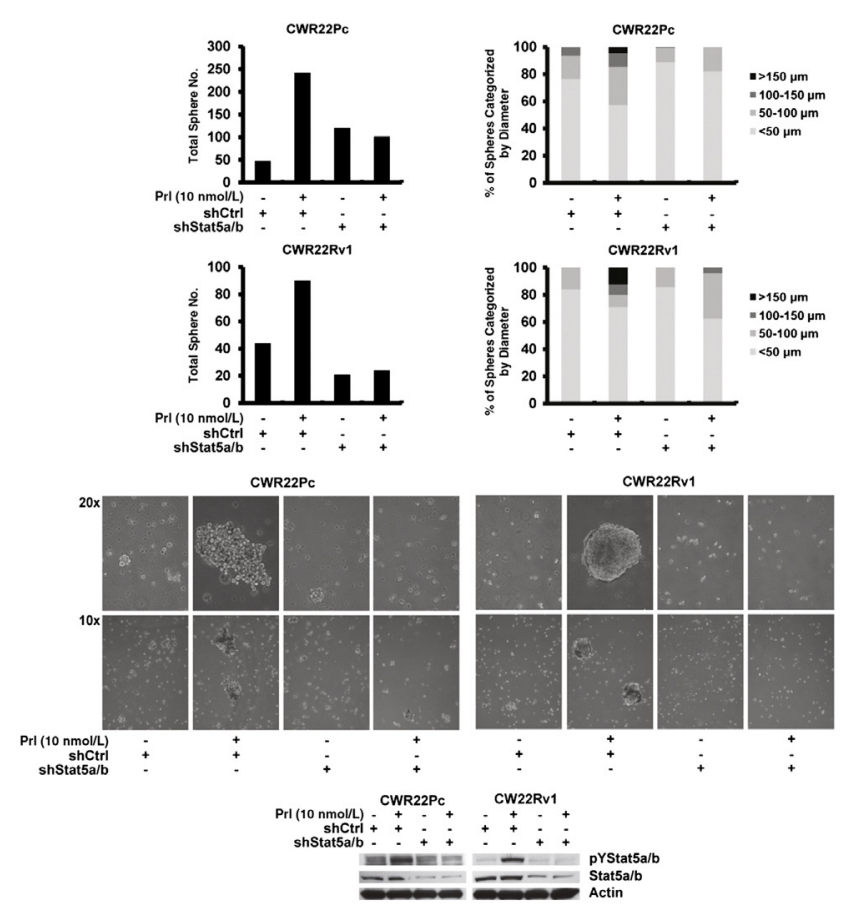

B

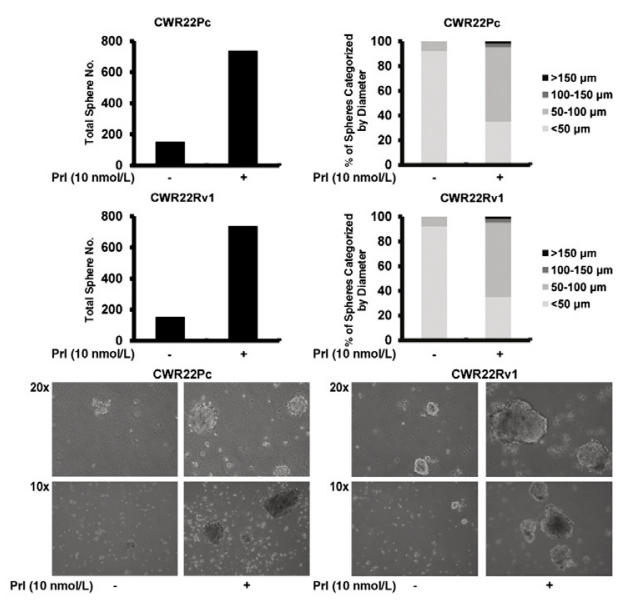

D

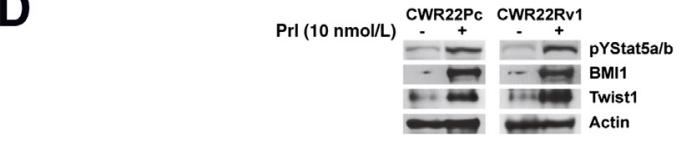

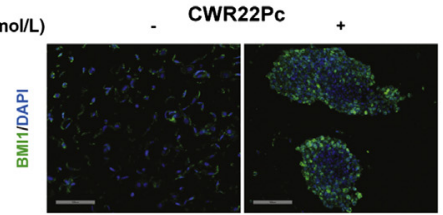

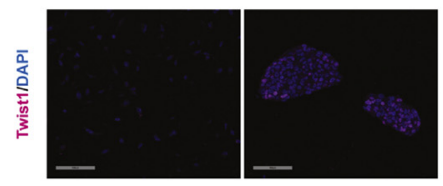

CWR22Rv1

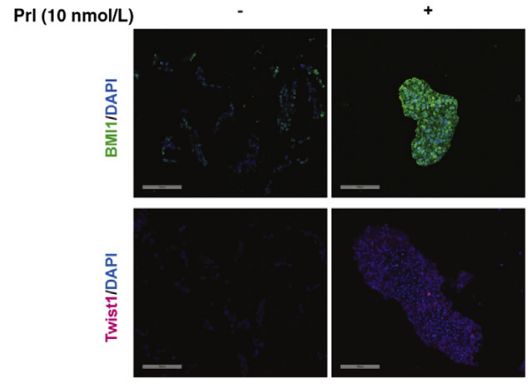

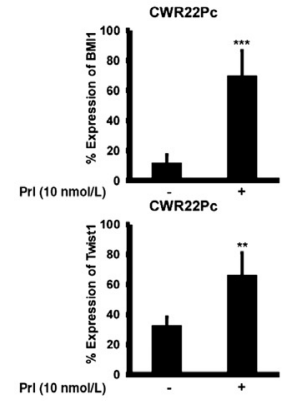

(1000

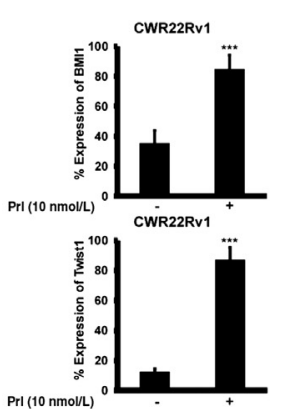

Figure 6 Active Jak2-Stat5a/b signaling induces stem-like properties of prostate cancer (PC) cells. A: Activation of Jak2-Stat5a/b signaling induces mRNA levels of epithelial-to-mesenchymal transition (EMT) and stem-like markers in PC cells. CWR22Pc and CWR22Rv1 cells were serum starved for 16 hours and treated with $10 \mathrm{nmol} / \mathrm{L}$ prolactin (Prl) for 48 hours, followed by replating and growth on low-attachment plates in stem cell medium for 7 days. Relative expression of mRNAs for markers of EMT [E-cadherin (E-Cad), N-cadherin (N-Cad), and Twist1] and stem-like cells (BMI1, CD44, and Sox2) was determined by real-time quantitative PCR and normalized to glyceraldehyde-3-phosphate dehydrogenase mRNA. B: Active Jak2-Stat5a/b promotes sphere formation of PC cells grown in stem cell culture conditions described in A. Total number and diameter of the spheres were quantified using automated software (ImageJ). Representative images are shown. C: Genetic knockdown of Stat5a/b inhibits the formation of PC spheres induced by $10 \mathrm{nmol} / \mathrm{L}$ Prl. CWR22Pc and CWR22Rv1 cells were transduced with lentiviral shRNA targeting control (shCtrl) or Stat5a/b (shStat5a/b) for 48 hours, after which Prl-induced Stat5a/b activation and shRNA knockdown were verified by immunoblotting, followed by replating and growth in stem cell culture conditions in the presence or absence of Prl for 4 days. D: Active Stat5a/b induces a concurrent increase in Twist1 and BMI1 levels in PC stem cell spheres. Whole cell lysates from PC cells described in A were immunoblotted for pYStat5a/b, BMI1, and Twist1, and equal protein loading was confirmed by actin expression. Formalin-fixed, paraffin-embedded CWR22Pc and CW22Rv1 cell pellets were immunostained for DAPI, BMI1, and Twist1 by immunofluorescence cytochemistry. Statistical significance was calculated by unpaired $t$-test. ${ }^{* *} P<0.01,{ }^{* *} P<0.001$.

BMI1 is known to maintain self-renewal potential of $\mathrm{PC},{ }^{30-33}$ we investigated the possibility that BMI1 mediates Jak2-Stat5a/b induction of stem-like properties in PC cells. As shown by immunoblotting and immunofluorescence cytochemistry, PC cell spheres induced by Jak2-Stat5a/b signaling displayed elevated levels of both BMI1 $(P<0.001)$ and Twist $(P<0.01)$ protein expression (Figure 6D). 
A
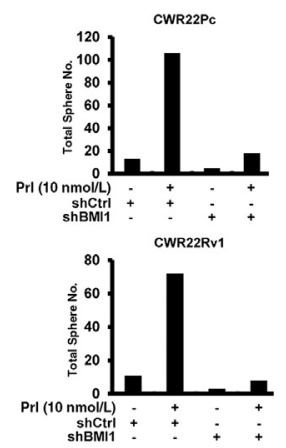

CWR22PG
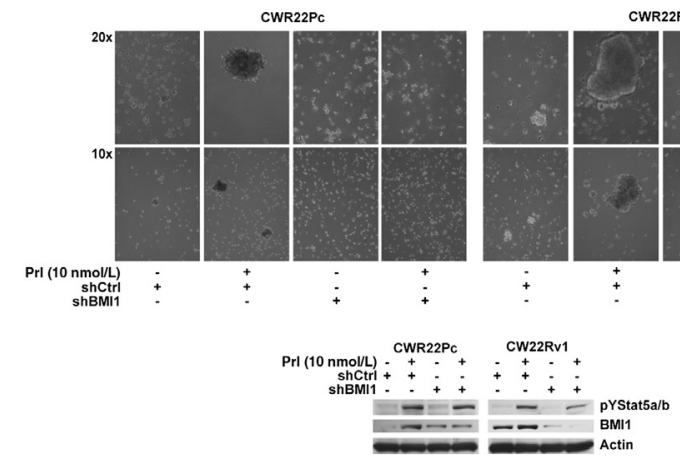

C

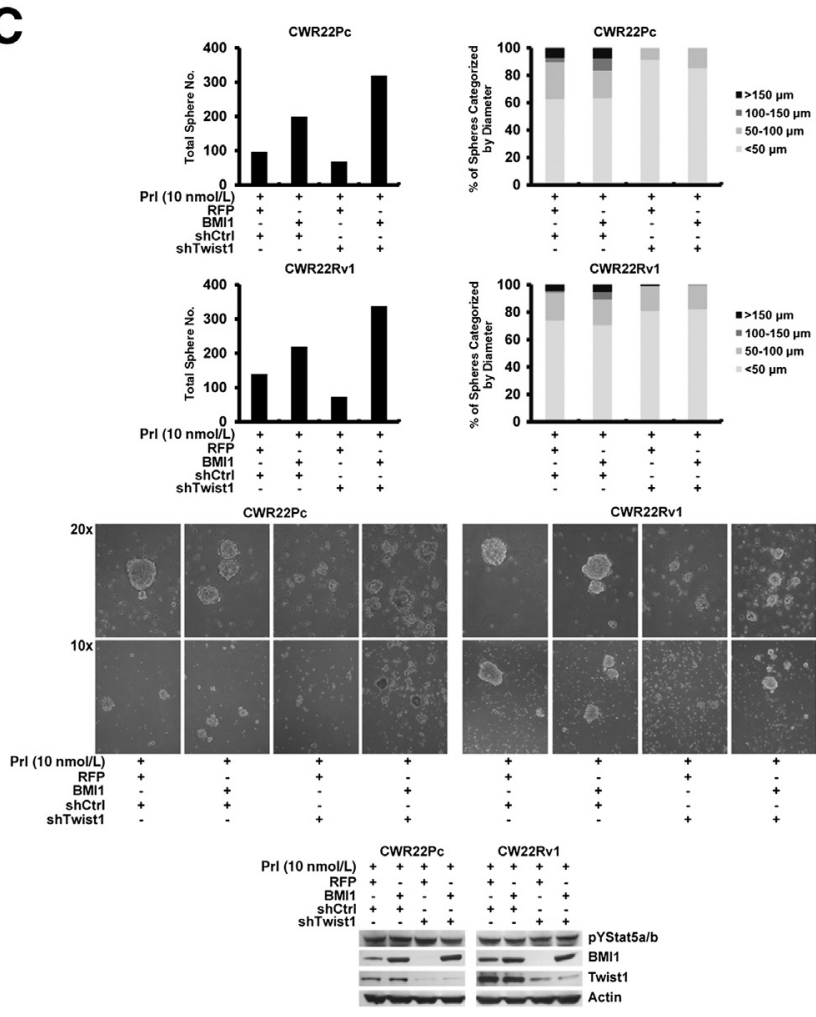

B
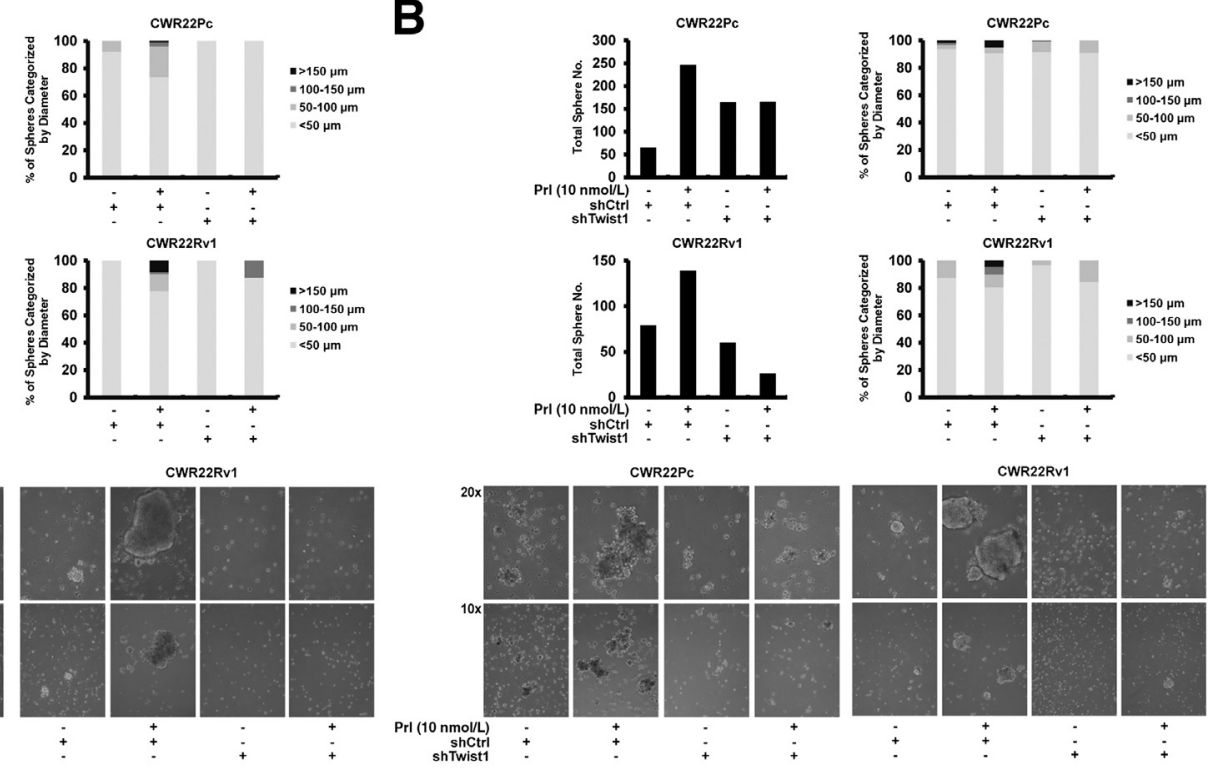

CWR22Pc
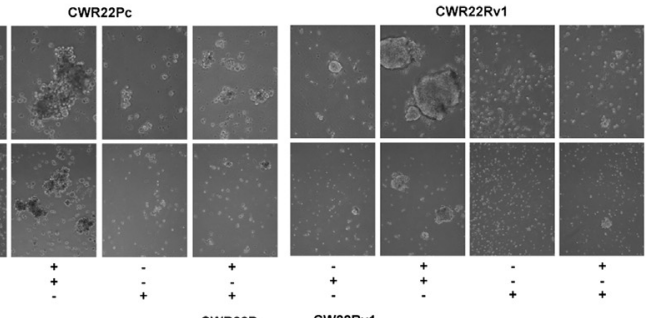

Prl (10 nmoll) $\begin{gathered}\text { CWR22PC } \\ \text { shCtrl } \\ \text { shTwist } \\ + \\ + \\ +\end{gathered}$

$=+ \pm \pm+ \pm$ pYStat5a/b

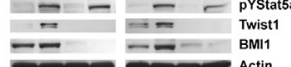

Figure 7 Active Jak2-Stat5a/b signaling promotes stem-like properties in prostate cancer $(\mathrm{PC})$ cells through regulation of both Twist1 and Bmi1. A and B: Down-regulation of either BMI1 or Twist1 expression suppresses formation of PC spheres generated by Jak2Stat5a/b signaling. BMI1 and Twist1 were genetically knocked down in PC cells by lentiviral shRNA targeting control (shCtrl) versus BMI1 (shBMI1; A) or Twist1 (shTwist1; B) for 48 hours, as shown by Western blot analysis, after which the cells were resuspended onto low-adherence plates in stem cell medium with or without $10 \mathrm{nmol} / \mathrm{L}$ prolactin (Prl) for 4 days. Graphs of total number and diameter of spheres and representative images are shown. C: Overexpression of shRNA-resistant BMI1 after genetic knockdown of Twist1 in PC cells treated with Prl rescue formation of Jak2Stat5a/b-induced PC cell spheres. CWR22Pc and CWR22Rv1 cells were transduced with lentiviral shCtrl or shTwist1 for 48 hours, after which BMI1 was exogenously introduced to the cells using lentivirus expressing shRNA-resistant BMI1 for 72 hours. Successful gene transduction is demonstrated by Western blot analysis. PC cells were resuspended and grown on low-adherence plates in stem cell medium in the presence of $10 \mathrm{nmol} / \mathrm{L}$ Prl for 7 days. Graphs of total number and diameter of spheres and representative images are shown.

To mechanistically evaluate if BMI 1 is involved in mediation of active Jak2-Stat5a/b induction of stem-like properties in PC cells, we genetically knocked down BMI1 (shRNA targeting BMI1) during Prl treatment of CWR22Pc and CWR22Rv1 cells cultured in stem cell culture conditions using lentivirus. shRNA targeting BMI1 suppressed the number and size of PC cell spheres induced by active Jak2-Stat5a/b signaling in stem cell culture conditions (Figure 7A), suggesting that BMI1 is critical for Jak2Stat5a/b induction of the stem-like PC cell phenotype. Finally, given that BMI1 has been shown to be regulated by Twist1 in cancer cells ${ }^{34}$ and that Jak2-Stat5a/b signaling 
A

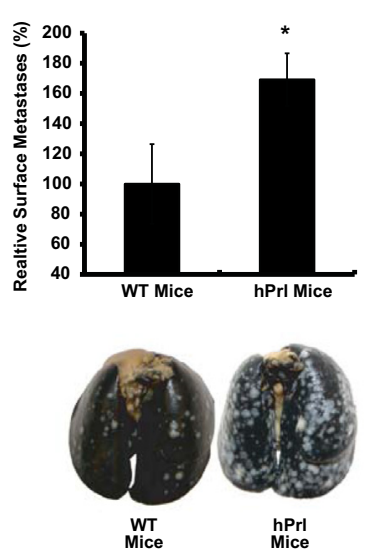

C
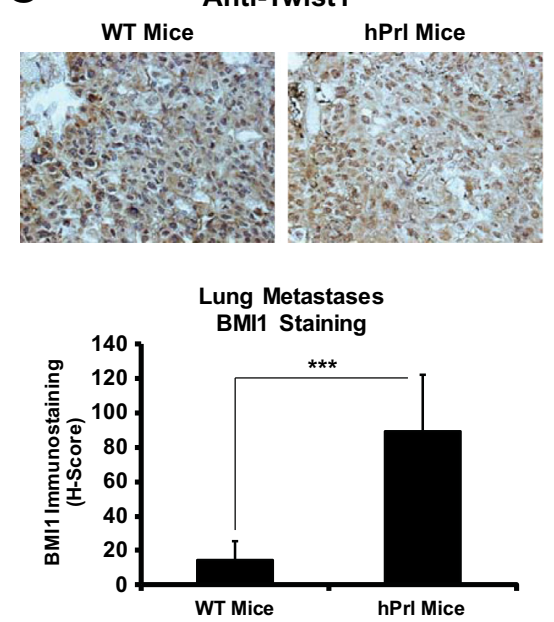

B
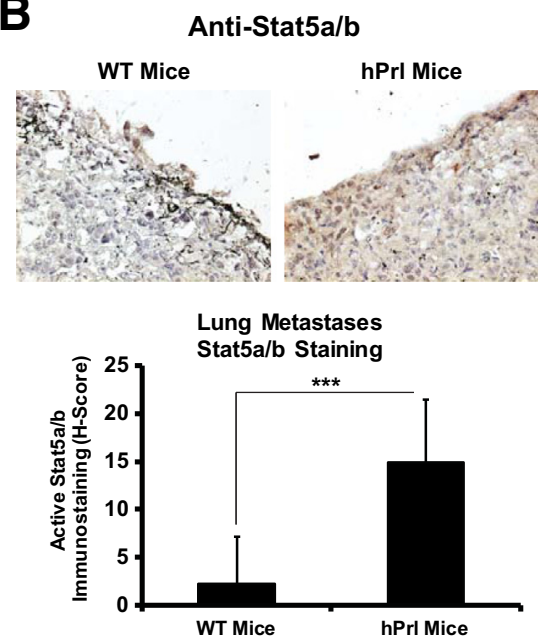

Anti-BMI1
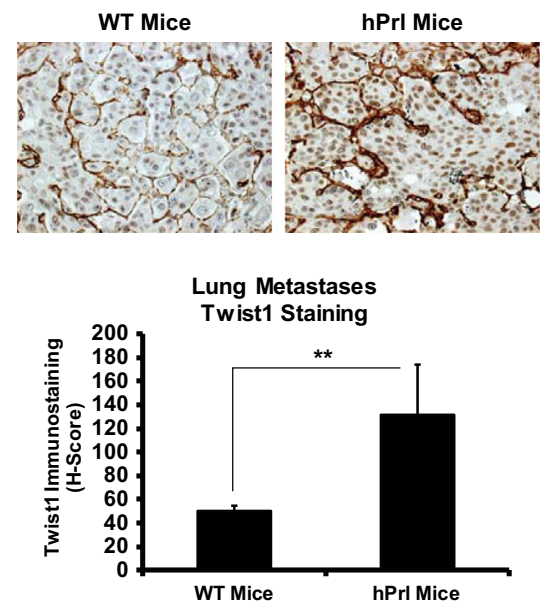

Figure 8 Prolactin (Prl)-Jak2-Stat5a/b signaling promotes metastasis colonization of prostate cancer (PC) cells in vivo. A: Inoculation of $\mathrm{PC}$ cells into mice expressing human Prl (hPrl) results in more lung metastases compared with control. DU145 cells expressing adenoviral PrlR (multiplicity of infection, 5) were inoculated into the tail veins of human Prl-expressing nonobese diabetic - severe combined immunodeficiencyIL-2 receptor $\gamma$ (hPrl.NSG) mice or wild-type (WT). NSG mice (three to four mice per group). Lungs were harvested, fixed, and stained, and metastases were quantified by ImageJ software. Representative images of India ink-stained lungs from the mice are shown $(P=0.05)$. B and C: Metastatic foci are counterstained white using Fekete's solution. Immunohistochemical analysis of lung metastases shows induction of active Stat $5 a / b$ expression in hPrl.NSG mice (B), which coincides with robust Twist1 and BMI1 expression (C). Immunohistochemistry of fixed, paraffinembedded lungs for nuclear active Stat5a/b (B) and Twist1 and BMI1 (C) was conducted using biotin-streptavidin-amplified peroxidase antiperoxidase immunodetection. Statistical significance was calculated using an exact Wilcoxon rank-sum test in $\mathbf{A}$ and using a linear mixedeffects model with empirical SEMs. ${ }^{*} P<0.05$, $* * P<0.01$, and $* * * P<0.001$. up-regulates Twist1 expression in PC cells (Figures 1, 2, 3, and 5), we examined if Twist1 is required for the Stat5a/binduced stem-like phenotype of PC cells. Loss of Twist1 expression (shTwist1) suppressed sphere formation induced by active Jak2-Stat5a/b signaling in PC cells, leading to simultaneous down-regulation of BMI1 protein expression (Figure 7B), suggesting that Twist1 is critical for Stat5a/binduced stem-like cell properties in PC cells. Lentiviral delivery of shRNA-resistant BMI1 in Twist1-depleted (shTwist1) CWR22Pc and CWR22Rv1 cells treated with Prl for 7 days rescued the formation of Prl induction of PC cell spheres in stem cell culture conditions (Figure 7C). In summary, these data suggest that active Jak2-Stat5a/b signaling promotes stem-like cell properties in PC cells through regulation of both Twist1 and BMI1.

\section{Prl-Induced Jak2-Stat5a/b Signaling Promotes Metastases Formation in Vivo}

Having established the significance of Prl-induced activation of Stat5a/b in the induction of EMT and cancer stem-like properties, we evaluated if activation of the Prl-Jak2-Stat5a/b signaling cascade promotes metastatic colonization of PC cells in vivo. Mouse prolactin is a poor agonist and a partial antagonist of human PrlR and, therefore, mouse Prl fails to activate PrlR-Jak2-Stat5a/b signaling in human cancer cells when grown in mice. ${ }^{80}$ To overcome this limitation, we used a genetically engineered mouse model (hPrl.NSG) in which $\mathrm{hPrl}$ has been knocked into the mouse Prl gene locus, followed by backcrossing for 10 generations into the NSGimmunodeficient mouse strain. This model provides a unique system to evaluate the impact of Prl-activated Jak2Stat5a/b signaling in the metastatic colonization of human $\mathrm{PC}$ cells grown in mice in vivo. Inoculation of PrlRexpressing DU145 cells into the tail vein of male hPrl.NSG or WT.NSG mice (Ctrl) resulted in a $69 \%$ increase in metastasis formation at 8 weeks in hPrl.NSG mice compared with Ctrl mice (Figure 8A). Furthermore, comparison of lung tissues derived from WT.NSG mice versus hPrl.NSG mice showed that lungs from hPrl.NSG mice at 8 weeks after inoculation expressed elevated Stat5a/b activation (Figure $8 \mathrm{~B})(P<0.001)$, which corresponded with robust expression of Twist1 $(P<0.001)$ and BMI1 $(P<0.01)$ (Figure $8 \mathrm{C}$ ). These results support the notion that Prl-Jak2- 
Stat5a/b signaling promotes metastatic colonization of PC cells in vivo and is associated with $S$ Stat $5 \mathrm{a} / \mathrm{b}$ activation.

\section{Discussion}

The emergence of systemic disease is the major cause of PC-related deaths and, therefore, determination of molecular mechanisms underlying metastatic dissemination of PC is crucial for identification of new targets for therapy development for PC. In the present work, we demonstrate that Jak2-Stat5a/b signaling induced both molecular markers and functional end points of EMT in PC in vitro and metastatic colonization of PC cells in vivo in mice. Mechanistically, our data indicate that Twist1 is a critical mediator of Jak2Stat5a/b induction of EMT in PC cells, whereby genetic knockdown of Twist1 expression led to a loss of EMTassociated molecular and functional changes in PC cells. At the same time, active Jak2-Stat5a/b signaling induced cancer stem-like properties, including sphere formation of PC cells and expression of proteins characteristic to cancer stem-like cells simultaneously with up-regulation of EMT markers. Finally, our results suggest that active Stat5a/b induces cancer stem-like properties through up-regulation of both Twist1 and BMI1 in PC cells.

One of the key results is that active Jak2-Stat5a/b signaling induces the EMT program in PC cells. Specifically, active Stat5a/b increased expression of mesenchymal markers, such as $\mathrm{N}$-cadherin, vimentin, and fibronectin, while down-regulating levels of E-cadherin in PC cells, xenograft tumors, and patient-derived clinical PCs ex vivo. In addition, active Stat5a/b induced phenotypic changes in PC cells by disruption of PC cell growth as epithelial monolayers, and active Stat5a/b induced adhesion and migration of PC cells to fibronectin. Pharmacological and genetic knockdown of Jak2 and Stat5a/b suppressed both Prl-induced changes in expression of mesenchymal markers in PC cells and Prl-induced up-regulation of functional end points of EMT, indicating critical roles for both Jak2 and $\mathrm{Stat} 5 \mathrm{a} / \mathrm{b}$ in promoting EMT in PC.

The role of AR regulation of EMT in PC cells remains inconclusive. AR signaling has been linked with induction of EMT in PC cells ${ }^{81}$ and, at the same time, with suppression of EMT in PC. ${ }^{82-84}$ Our data show active Stat5a/binduced EMT in DU145 cells, which do not express AR, suggesting that there are distinct AR-independent mechanisms of Stat5a/b promotion of EMT. Moreover, our data in AR-positive cell lines suggested that AR regulation of EMT markers was in opposition to the effects of active Stat5a/b, which further supports the concept of $S t a t 5 \mathrm{a} / \mathrm{b}$ regulation of EMT independently of AR in PC cells. We have previously demonstrated that the Stat5a/b gene locus undergoes amplification in approximately $30 \%$ of distant CRPC metastases, ${ }^{46}$ and that Stat5a/b is critical for CRPC growth. ${ }^{38}$ Collectively, the findings of the present study provide the basis for future studies that will focus on Stat5a/b regulation of emergence of EMT during CR growth of PC during pharmacological or surgical androgen deprivation.

Jak2-Stat5a/b signaling up-regulated expression of Twist 1 in PC cells, xenograft tumors, and clinical PCs ex vivo. Moreover, genetic knockdown of Twist1 suppressed Stat5a/ b-induced changes in EMT marker expression in PC cells and migration and adhesion of PC cells to fibronectin. Reexpression of shRNA-resistant Twist1 was able to rescue expression of EMT markers in the presence of active Stat5a/b. These findings support the concept that Twist1 is a mediator of Stat $5 \mathrm{a} / \mathrm{b}$ induction of EMT-associated changes in PC. Twist1 is an established repressor of E-cadherin gene transcription during EMT, ${ }^{14,15}$ and it directly induces $\mathrm{N}$-cadherin expression in PC cells. ${ }^{16}$ Moreover, Twist1 has been shown to induce RAC1 activity ${ }^{22}$ and formation of invadopodia in cancer cells. ${ }^{24}$ The regulatory regions of the Twist1 gene contain the $\gamma$-interferon-activated sequence, ${ }^{85}$ a binding element shared by Stat 3 and Stat5a/ $\mathrm{b}$, and Stat 3 has been shown to up-regulate Twist1 gene expression in breast cancer cells. ${ }^{85,86}$ To our knowledge, the work presented herein provides the first evidence of active Stat5a/b signaling inducing Twist 1 gene expression in PC. Twist1 expression was regulated by Stat5a/b at both mRNA and protein levels in PC cells. Whether active Stat $5 \mathrm{a} / \mathrm{b}$ acts through direct binding of the Twist 1 promoter in PC will need to be addressed in future work.

Active Stat5a/b increased sphere formation of PC cells concurrent with induction of markers associated with cancer stem-like properties and EMT in PC cells. Specifically, Prlactivated Stat5a/b increased sphere formation of PC cells when grown in stem cell culture conditions, which was suppressed by genetic knockdown of Stat $5 \mathrm{a} / \mathrm{b}$, suggesting that $S t a t 5 \mathrm{a} / \mathrm{b}$ is a key factor promoting phenotypic changes associated with increased self-renewal capability of PC cells. At the same time, Prl-activated Stat5a/b induced EMT marker expression, including Twist1, in PC cell spheres simultaneously with up-regulation of CD44, Sox2, and BMI1. Notably, Stat5a/b activation resulted in a robust increase of not only mRNA but also protein expression of BMI1 in PC cell spheres. Consistent with its role in inhibiting $\mathrm{p} 16^{\mathrm{INK} 4 \mathrm{a}}$ and $\mathrm{p} 14^{\mathrm{ARF}}$ transcription by inducing chromatin condensation at the respective gene loci, BMI triggers bypass of senescence in cancer cells. ${ }^{31-34,87}$ More important, our results support this concept because genetic knockdown of BMI1 impaired active Stat5a/b-induced sphere formation of PC cells. BMI1, in turn, has been shown to be directly up-regulated by Twist1 through the Twist1-binding site in intron1 of the BMI1 gene. ${ }^{34}$ Here, our data indicate that genetic knockdown of Twist1 suppressed Stat5a/b-induced BMI1 expression and sphere formation of PC cells. Lentiviral re-expression of BMI1 in Twist1-depleted PC cells was able to rescue the formation of PC cell spheres in the presence of active Stat5a/b. Collectively, these results suggest that active $S t a t 5 \mathrm{a} / \mathrm{b}$-induced expression of Twist1 promotes sphere formation of PC cells through up-regulation of BMI1. Twist1 and BMI1 
have both been shown to bind to E-cadherin promoter to down-regulate E-cadherin gene expression. ${ }^{34}$ Future work will need to assess if both Twist1 and BMI1 are required for suppression of E-cadherin in PC. The concept of linkage between EMT and cancer stem-like properties has been demonstrated in various cancer types. ${ }^{25,26,34,36} \mathrm{Prl}$ has been previously linked with an increase of stem-like cell subpopulation in prostate of a mouse model and in prostate-specific Prl transgenic mice. ${ }^{88}$ Our data presented herein suggest, for the first time, that the Jak2-Stat5a/b-Twist1-BMI1 signaling axis may enable both invasive and self-renewal potential in human PC cells, hallmarks of metastatic disease.

Finally, activation of the Jak2-Stat5a/b signaling pathway increased metastatic colonization of PC cells to the lungs of mice in vivo. Use of a unique mouse model that expresses human Prl instead of mouse Prl, thus fully activating PrlR in human cells, enabled us to test the impact of ligand-induced activation of Stat5a/b signaling on the metastatic capacity of PC cells of human origin in an in vivo setting in mice. Colonization of cancer cells in the lungs involves docking of circulating cancer cells within premetastatic niches in the microvasculature. ${ }^{7-9}$ Our data demonstrated that active $\mathrm{Stat} 5 \mathrm{a} / \mathrm{b}$ induces adhesion and migration of PC cells to fibronectin, which is consistent with in vivo findings of Stat5a/b promotion of metastases formation in lungs because premetastatic niches are rich in fibronectin deposits. ${ }^{4,6}$ In conclusion, development of pharmacological inhibitors of Stat5a/b signaling may provide an effective therapeutic strategy to prevent metastatic dissemination of PC.

\section{Acknowledgment}

We thank Dr. Michele Weiss (Thomas Jefferson University, Philadelphia, PA) for her help with the shRNA-resistant Twist1 lentivirus construct.

\section{Supplemental Data}

Supplemental material for this article can be found at http://dx.doi.org/10.1016/j.ajpath.2015.04.026.

\section{References}

1. Mundy GR: Metastasis to bone: causes, consequences and therapeutic opportunities. Nat Rev Cancer 2002, 2:584-593

2. Tomita K, van Bokhoven A, van Leenders GJ, Ruijter ET, Jansen CF, Bussemakers MJ, Schalken JA: Cadherin switching in human prostate cancer progression. Cancer Res 2000, 60:3650-3654

3. Kalluri R, Weinberg RA: The basics of epithelial-mesenchymal transition. J Clin Invest 2009, 119:1420-1428

4. Kaplan RN, Riba RD, Zacharoulis S, Bramley AH, Vincent L, Costa C, MacDonald DD, Jin DK, Shido K, Kerns SA, Zhu Z, Hicklin D, Wu Y, Port JL, Altorki N, Port ER, Ruggero D, Shmelkov SV, Jensen KK, Rafii S, Lyden D: VEGFR1-positive haematopoietic bone marrow progenitors initiate the pre-metastatic niche. Nature 2005, 438:820-827
5. Peinado H, Lavotshkin S, Lyden D: The secreted factors responsible for pre-metastatic niche formation: old sayings and new thoughts. Semin Cancer Biol 2011, 21:139-146

6. Erler JT, Bennewith KL, Cox TR, Lang G, Bird D, Koong A, Le QT, Giaccia AJ: Hypoxia-induced lysyl oxidase is a critical mediator of bone marrow cell recruitment to form the premetastatic niche. Cancer Cell 2009, 15:35-44

7. Kaplan RN, Rafii S, Lyden D: Preparing the "soil": the premetastatic niche. Cancer Res 2006, 66:11089-11093

8. Steeg PS: Cancer biology: emissaries set up new sites. Nature 2005, 438:750-751

9. Shiozawa Y, Pedersen EA, Havens AM, Jung Y, Mishra A, Joseph J, Kim JK, Patel LR, Ying C, Ziegler AM, Pienta MJ, Song J, Wang J, Loberg RD, Krebsbach PH, Pienta KJ, Taichman RS: Human prostate cancer metastases target the hematopoietic stem cell niche to establish footholds in mouse bone marrow. J Clin Invest 2011, 121:1298-1312

10. Gravdal K, Halvorsen OJ, Haukaas SA, Akslen LA: A switch from E-cadherin to $\mathrm{N}$-cadherin expression indicates epithelial to mesenchymal transition and is of strong and independent importance for the progress of prostate cancer. Clin Cancer Res 2007, 13:7003-7011

11. Tanaka H, Kono E, Tran CP, Miyazaki H, Yamashiro J, Shimomura T, Fazli L, Wada R, Huang J, Vessella RL, An J, Horvath S, Gleave M, Rettig MB, Wainberg ZA, Reiter RE: Monoclonal antibody targeting of N-cadherin inhibits prostate cancer growth, metastasis and castration resistance. Nat Med 2010, 16:1414-1420

12. Graff JR, Gabrielson E, Fujii H, Baylin SB, Herman JG: Methylation patterns of the E-cadherin 5' CpG island are unstable and reflect the dynamic, heterogeneous loss of E-cadherin expression during metastatic progression. J Biol Chem 2000, 275:2727-2732

13. Yoshiura K, Kanai Y, Ochiai A, Shimoyama Y, Sugimura T, Hirohashi S: Silencing of the E-cadherin invasion-suppressor gene by CpG methylation in human carcinomas. Proc Natl Acad Sci U S A 1995, 92:7416-7419

14. Yang J, Mani SA, Donaher JL, Ramaswamy S, Itzykson RA, Come C, Savagner P, Gitelman I, Richardson A, Weinberg RA: Twist, a master regulator of morphogenesis, plays an essential role in tumor metastasis. Cell 2004, 117:927-939

15. Qin Q, Xu Y, He T, Qin C, Xu J: Normal and disease-related biological functions of Twist1 and underlying molecular mechanisms. Cell Res 2012, 22:90-106

16. Alexander NR, Tran NL, Rekapally H, Summers CE, Glackin C, Heimark RL: N-cadherin gene expression in prostate carcinoma is modulated by integrin-dependent nuclear translocation of Twist1. Cancer Res 2006, 66:3365-3369

17. Zheng H, Kang Y: Multilayer control of the EMT master regulators. Oncogene 2014, 33:1755-1763

18. Kwok WK, Ling MT, Lee TW, Lau TC, Zhou C, Zhang X, Chua CW, Chan KW, Chan FL, Glackin C, Wong YC, Wang X: Upregulation of TWIST in prostate cancer and its implication as a therapeutic target. Cancer Res 2005, 65:5153-5162

19. Weiss MB, Abel EV, Mayberry MM, Basile KJ, Berger AC, Aplin AE: TWIST1 is an ERK1/2 effector that promotes invasion and regulates MMP-1 expression in human melanoma cells. Cancer Res 2012, 72:6382-6392

20. Mikheeva SA, Mikheev AM, Petit A, Beyer R, Oxford RG Khorasani L, Maxwell JP, Glackin CA, Wakimoto H, GonzalezHerrero I, Sanchez-Garcia I, Silber JR, Horner PJ, Rostomily RC: TWIST1 promotes invasion through mesenchymal change in human glioblastoma. Mol Cancer 2010, 9:194

21. Yang Z, Zhang X, Gang H, Li X, Li Z, Wang T, Han J, Luo T, Wen F, Wu X: Up-regulation of gastric cancer cell invasion by Twist is accompanied by $\mathrm{N}$-cadherin and fibronectin expression. Biochem Biophys Res Commun 2007, 358:925-930

22. Yang WH, Lan HY, Huang CH, Tai SK, Tzeng CH, Kao SY, Wu KJ, Hung MC, Yang MH: RAC1 activation mediates Twist1-induced cancer cell migration. Nat Cell Biol 2012, 14:366-374 
23. Kang Y, Massague J: Epithelial-mesenchymal transitions: twist in development and metastasis. Cell 2004, 118:277-279

24. Eckert MA, Lwin TM, Chang AT, Kim J, Danis E, Ohno-Machado L, Yang J: Twist1-induced invadopodia formation promotes tumor metastasis. Cancer Cell 2011, 19:372-386

25. Mani SA, Guo W, Liao MJ, Eaton EN, Ayyanan A, Zhou AY, Brooks M, Reinhard F, Zhang CC, Shipitsin M, Campbell LL, Polyak K, Brisken C, Yang J, Weinberg RA: The epithelialmesenchymal transition generates cells with properties of stem cells. Cell 2008, 133:704-715

26. Morel AP, Lievre M, Thomas C, Hinkal G, Ansieau S, Puisieux A: Generation of breast cancer stem cells through epithelialmesenchymal transition. PLoS One 2008, 3:e2888

27. Armstrong AJ, Marengo MS, Oltean S, Kemeny G, Bitting RL, Turnbull JD, Herold CI, Marcom PK, George DJ, Garcia-Blanco MA: Circulating tumor cells from patients with advanced prostate and breast cancer display both epithelial and mesenchymal markers. Mol Cancer Res 2011, 9:997-1007

28. Collins AT, Berry PA, Hyde C, Stower MJ, Maitland NJ: Prospective identification of tumorigenic prostate cancer stem cells. Cancer Res 2005, 65:10946-10951

29. Gu G, Yuan J, Wills M, Kasper S: Prostate cancer cells with stem cell characteristics reconstitute the original human tumor in vivo. Cancer Res 2007, 67:4807-4815

30. Lukacs RU, Memarzadeh S, Wu H, Witte ON: Bmi-1 is a crucial regulator of prostate stem cell self-renewal and malignant transformation. Cell Stem Cell 2010, 7:682-693

31. Jacobs JJ, Kieboom K, Marino S, DePinho RA, van Lohuizen M: The oncogene and Polycomb-group gene bmi-1 regulates cell proliferation and senescence through the ink4a locus. Nature 1999, 397:164-168

32. Sharpless NE, DePinho RA: The INK4A/ARF locus and its two gene products. Curr Opin Genet Dev 1999, 9:22-30

33. Park IK, Morrison SJ, Clarke MF: Bmi1, stem cells, and senescence regulation. J Clin Invest 2004, 113:175-179

34. Yang MH, Hsu DS, Wang HW, Wang HJ, Lan HY, Yang WH, Huang CH, Kao SY, Tzeng CH, Tai SK, Chang SY, Lee OK, Wu KJ: Bmil is essential in Twist1-induced epithelial-mesenchymal transition. Nat Cell Biol 2010, 12:982-992

35. Kong D, Banerjee S, Ahmad A, Li Y, Wang Z, Sethi S, Sarkar FH: Epithelial to mesenchymal transition is mechanistically linked with stem cell signatures in prostate cancer cells. PLoS One 2010, 5: e12445

36. Song LB, Li J, Liao WT, Feng Y, Yu CP, Hu LJ, Kong QL, Xu LH, Zhang X, Liu WL, Li MZ, Zhang L, Kang TB, Fu LW, Huang WL, Xia YF, Tsao SW, Li M, Band V, Band H, Shi QH, Zeng YX, Zeng MS: The polycomb group protein Bmi-1 represses the tumor suppressor PTEN and induces epithelial-mesenchymal transition in human nasopharyngeal epithelial cells. J Clin Invest 2009, 119:3626-3636

37. Ahonen TJ, Xie J, LeBaron MJ, Zhu J, Nurmi M, Alanen K, Rui H, Nevalainen MT: Inhibition of transcription factor Stat5 induces cell death of human prostate cancer cells. J Biol Chem 2003, 278: 27287-27292

38. Gu L, Liao Z, Hoang DT, Dagvadorj A, Gupta S, Blackmon S, Ellsworth E, Talati P, Leiby B, Zinda M, Lallas CD, Trabulsi EJ, McCue P, Gomella L, Huszar D, Nevalainen MT: Pharmacologic inhibition of Jak2-Stat5 signaling by Jak2 inhibitor AZD1480 potently suppresses growth of both primary and castrate-resistant prostate cancer. Clin Cancer Res 2013, 19:5658-5674

39. Gu L, Dagvadorj A, Lutz J, Leiby B, Bonuccelli G, Lisanti MP, Addya S, Fortina P, Dasgupta A, Hyslop T, Bubendorf L, Nevalainen MT: Transcription factor Stat3 stimulates metastatic behavior of human prostate cancer cells in vivo, whereas Stat5b has a preferential role in the promotion of prostate cancer cell viability and tumor growth. Am J Pathol 2010, 176:1959-1972

40. Dagvadorj A, Collins S, Jomain JB, Abdulghani J, Karras J, Zellweger T, Li H, Nurmi M, Alanen K, Mirtti T, Visakorpi T, Bubendorf L, Goffin V, Nevalainen MT: Autocrine prolactin promotes prostate cancer cell growth via Janus kinase-2-signal transducer and activator of transcription-5a/b signaling pathway. Endocrinology 2007, 148:3089-3101

41. Dagvadorj A, Kirken RA, Leiby B, Karras J, Nevalainen MT: Transcription factor signal transducer and activator of transcription 5 promotes growth of human prostate cancer cells in vivo. Clin Cancer Res 2008, 14:1317-1324

42. Kazansky AV, Spencer DM, Greenberg NM: Activation of signal transducer and activator of transcription 5 is required for progression of autochthonous prostate cancer: evidence from the transgenic adenocarcinoma of the mouse prostate system. Cancer Res 2003, 63: $8757-8762$

43. Mirtti T, Leiby BE, Abdulghani J, Aaltonen E, Pavela M, Mamtani A, Alanen K, Egevad L, Granfors T, Josefsson A, Stattin P, Bergh A, Nevalainen MT: Nuclear Stat5a/b predicts early recurrence and prostate cancer-specific death in patients treated by radical prostatectomy. Hum Pathol 2013, 44:310-319

44. Gu L, Vogiatzi P, Puhr M, Dagvadorj A, Lutz J, Ryder A, Addya S, Fortina P, Cooper C, Leiby B, Dasgupta A, Hyslop T, Bubendorf L, Alanen K, Mirtti T, Nevalainen MT: Stat5 promotes metastatic behavior of human prostate cancer cells in vitro and in vivo. Endocr Relat Cancer 2010, 17:481-493

45. Li H, Ahonen TJ, Alanen K, Xie J, LeBaron MJ, Pretlow TG, Ealley EL, Zhang Y, Nurmi M, Singh B, Martikainen PM, Nevalainen MT: Activation of signal transducer and activator of transcription 5 in human prostate cancer is associated with high histological grade. Cancer Res 2004, 64:4774-4782

46. Haddad BR, Gu L, Mirtti T, Dagvadorj A, Vogiatzi P, Hoang DT, Bajaj R, Leiby B, Ellsworth E, Blackmon S, Ruiz C, Curtis M, Fortina P, Ertel A, Liu C, Rui H, Visakorpi T, Bubendorf L, Lallas CD, Trabulsi EJ, McCue P, Gomella L, Nevalainen MT: STAT5A/B gene locus undergoes amplification during human prostate cancer progression. Am J Pathol 2013, 182:2264-2275

47. Li H, Zhang Y, Glass A, Zellweger T, Gehan E, Bubendorf L, Gelmann EP, Nevalainen MT: Activation of signal transducer and activator of transcription-5 in prostate cancer predicts early recurrence. Clin Cancer Res 2005, 11:5863-5868

48. Thomas C, Zoubeidi A, Kuruma H, Fazli L, Lamoureux F, Beraldi E, Monia BP, MacLeod AR, Thuroff JW, Gleave ME: Transcription factor Stat5 knockdown enhances androgen receptor degradation and delays castration-resistant prostate cancer progression in vivo. Mol Cancer Ther 2011, 10:347-359

49. Hoang DT, Gu L, Liao Z, Shen F, Talati PG, Koptyra M, Tan SH, Ellsworth E, Gupta S, Montie H, Dagvadorj A, Savolainen S, Leiby B, Mirtti T, Merry DE, Nevalainen MT: Inhibition of Stat5a/b enhances proteasomal degradation of androgen receptor liganded by antiandrogens in prostate cancer. Mol Cancer Ther 2014, 14:1-14

50. Darnell JE Jr: STATs and gene regulation. Science 1997, 277: $1630-1635$

51. Levy DE, Darnell JE Jr: Stats: transcriptional control and biological impact. Nat Rev Mol Cell Biol 2002, 3:651-662

52. Rui H, Kirken RA, Farrar WL: Activation of receptor-associated tyrosine kinase JAK2 by prolactin. J Biol Chem 1994, 269:5364-5368

53. Rui H, Lebrun JJ, Kirken RA, Kelly PA, Farrar WL: JAK2 activation and cell proliferation induced by antibody-mediated prolactin receptor dimerization. Endocrinology 1994, 135:1299-1306

54. Campbell GS, Argetsinger LS, Ihle JN, Kelly PA, Rillema JA, CarterSu C: Activation of JAK2 tyrosine kinase by prolactin receptors in $\mathrm{Nb} 2$ cells and mouse mammary gland explants. Proc Natl Acad Sci U S A 1994, 91:5232-5236

55. Soldaini E, John S, Moro S, Bollenbacher J, Schindler U, Leonard WJ: DNA binding site selection of dimeric and tetrameric Stat5 proteins reveals a large repertoire of divergent tetrameric Stat5a binding sites. Mol Cell Biol 2000, 20:389-401

56. Horvath CM, Wen Z, Darnell JE Jr: A STAT protein domain that determines DNA sequence recognition suggests a novel DNAbinding domain. Genes Dev 1995, 9:984-994 
57. Nevalainen MT, Valve EM, Ingleton PM, Nurmi M, Martikainen PM, Harkonen PL: Prolactin and prolactin receptors are expressed and functioning in human prostate. J Clin Invest 1997, 99:618-627

58. Weiss-Messer E, Merom O, Adi A, Karry R, Bidosee M, Ber R, Kaploun A, Stein A, Barkey RJ: Growth hormone $(\mathrm{GH})$ receptors in prostate cancer: gene expression in human tissues and cell lines and characterization, GH signaling and androgen receptor regulation in LNCaP cells. Mol Cell Endocrinol 2004, 220:109-123

59. Feldman L, Wang Y, Rhim JS, Bhattacharya N, Loda M, Sytkowski AJ: Erythropoietin stimulates growth and STAT5 phosphorylation in human prostate epithelial and prostate cancer cells. Prostate 2006, 66:135-145

60. Grasso AW, Wen D, Miller CM, Rhim JS, Pretlow TG, Kung HJ: ErbB kinases and NDF signaling in human prostate cancer cells. Oncogene 1997, 15:2705-2716

61. Dagvadorj A, Tan SH, Liao Z, Xie J, Nurmi M, Alanen K, Rui H, Mirtti T, Nevalainen MT: N-terminal truncation of Stat5a/b circumvents PIAS3-mediated transcriptional inhibition of Stat5 in prostate cancer cells. Int J Biochem Cell Biol 2010, 42:2037-2046

62. Graham FL, Prevec L: Manipulation of adenovirus vectors. Methods Mol Biol 1991, 7:109-128

63. Weiss MB, Abel EV, Dadpey N, Aplin AE: FOXD3 modulates migration through direct transcriptional repression of TWIST1 in melanoma. Mol Cancer Res 2014, 12:1314-1323

64. Hedvat M, Huszar D, Herrmann A, Gozgit JM, Schroeder A, Sheehy A, Buettner R, Proia D, Kowolik CM, Xin H, Armstrong B, Bebernitz G, Weng S, Wang L, Ye M, McEachern K, Chen H, Morosini D, Bell K, Alimzhanov M, Ioannidis S, McCoon P, Cao ZA, Yu H, Jove R, Zinda M: The JAK2 inhibitor AZD1480 potently blocks Stat 3 signaling and oncogenesis in solid tumors. Cancer Cell 2009, 16:487-497

65. Abdulghani J, Gu L, Dagvadorj A, Lutz J, Leiby B, Bonuccelli G, Lisanti MP, Zellweger T, Alanen K, Mirtti T, Visakorpi T, Bubendorf L, Nevalainen MT: Stat3 promotes metastatic progression of prostate cancer. Am J Pathol 2008, 172:1717-1728

66. Dubrovska A, Kim S, Salamone RJ, Walker JR, Maira SM, GarciaEcheverria C, Schultz PG, Reddy VA: The role of PTEN/Akt/PI3K signaling in the maintenance and viability of prostate cancer stem-like cell populations. Proc Natl Acad Sci U S A 2009, 106:268-273

67. Litvinov IV, Vander Griend DJ, Xu Y, Antony L, Dalrymple SL, Isaacs JT: Low-calcium serum-free defined medium selects for growth of normal prostatic epithelial stem cells. Cancer Res 2006, 66: 8598-8607

68. Lawson DA, Witte ON: Stem cells in prostate cancer initiation and progression. J Clin Invest 2007, 117:2044-2050

69. Nevalainen MT, Valve EM, Makela SI, Blauer M, Tuohimaa PJ, Harkonen PL: Estrogen and prolactin regulation of rat dorsal and lateral prostate in organ culture. Endocrinology 1991, 129:612-622

70. Nevalainen MT, Valve EM, Ahonen T, Yagi A, Paranko J, Harkonen PL: Androgen-dependent expression of prolactin in rat prostate epithelium in vivo and in organ culture. FASEB J 1997, 11: $1297-1307$

71. Ahonen TJ, Harkonen PL, Laine J, Rui H, Martikainen PM, Nevalainen MT: Prolactin is a survival factor for androgen-deprived rat dorsal and lateral prostate epithelium in organ culture. Endocrinology 1999, 140:5412-5421

72. Ahonen TJ, Harkonen PL, Rui H, Nevalainen MT: PRL signal transduction in the epithelial compartment of rat prostate maintained as long-term organ cultures in vitro. Endocrinology 2002, 143: 228-238

73. Nevalainen MT, Harkonen PL, Valve EM, Ping W, Nurmi M, Martikainen PM: Hormone regulation of human prostate in organ culture. Cancer Res 1993, 53:5199-5207
74. Dagvadorj A, Tan SH, Liao Z, Cavalli LR, Haddad BR, Nevalainen MT: Androgen-regulated and highly tumorigenic human prostate cancer cell line established from a transplantable primary CWR22 tumor. Clin Cancer Res 2008, 14:6062-6072

75. Tan SH, Dagvadorj A, Shen F, Gu L, Liao Z, Abdulghani J, Zhang Y, Gelmann EP, Zellweger T, Culig Z, Visakorpi T, Bubendorf L, Kirken RA, Karras J, Nevalainen MT: Transcription factor Stat5 synergizes with androgen receptor in prostate cancer cells. Cancer Res 2008, 68:236-248

76. Sultan AS, Xie J, LeBaron MJ, Ealley EL, Nevalainen MT, Rui H: Stat5 promotes homotypic adhesion and inhibits invasive characteristics of human breast cancer cells. Oncogene 2005, 24: 746-760

77. McCarty KS Jr, Miller LS, Cox EB, Konrath J, McCarty KS Sr: Estrogen receptor analyses: correlation of biochemical and immunohistochemical methods using monoclonal antireceptor antibodies. Arch Pathol Lab Med 1985, 109:716-721

78. Liu X, Robinson GW, Gouilleux F, Groner B, Hennighausen L: Cloning and expression of Stat5 and an additional homologue (Stat5b) involved in prolactin signal transduction in mouse mammary tissue. Proc Natl Acad Sci U S A 1995, 92:8831-8835

79. Schmitt-Ney M, Doppler W, Ball RK, Groner B: Beta-casein gene promoter activity is regulated by the hormone-mediated relief of transcriptional repression and a mammary-gland-specific nuclear factor. Mol Cell Biol 1991, 11:3745-3755

80. Utama FE, LeBaron MJ, Neilson LM, Sultan AS, Parlow AF, Wagner KU, Rui H: Human prolactin receptors are insensitive to mouse prolactin: implications for xenotransplant modeling of human breast cancer in mice. J Endocrinol 2006, 188:589-601

81. Zhu ML, Kyprianou N: Role of androgens and the androgen receptor in epithelial-mesenchymal transition and invasion of prostate cancer cells. FASEB J 2010, 24:769-777

82. Sun Y, Wang BE, Leong KG, Yue P, Li L, Jhunjhunwala S, Chen D, Seo K, Modrusan Z, Gao WQ, Settleman J, Johnson L: Androgen deprivation causes epithelial-mesenchymal transition in the prostate: implications for androgen-deprivation therapy. Cancer Res 2012, 72: $527-536$

83. Shiota M, Yokomizo A, Tada Y, Inokuchi J, Kashiwagi E, Masubuchi D, Eto M, Uchiumi T, Naito S: Castration resistance of prostate cancer cells caused by castration-induced oxidative stress through Twist1 and androgen receptor overexpression. Oncogene 2010, 29:237-250

84. Eide T, Ramberg H, Glackin C, Tindall D, Tasken KA: TWIST1, a novel androgen-regulated gene, is a target for NKX3-1 in prostate cancer cells. Cancer Cell Int 2013, 13:4-10

85. Cheng GZ, Zhang WZ, Sun M, Wang Q, Coppola D, Mansour M, Xu LM, Costanzo C, Cheng JQ, Wang LH: Twist is transcriptionally induced by activation of STAT3 and mediates STAT3 oncogenic function. J Biol Chem 2008, 283:14665-14673

86. Lo HW, Hsu SC, Xia W, Cao X, Shih JY, Wei Y, Abbruzzese JL, Hortobagyi GN, Hung MC: Epidermal growth factor receptor cooperates with signal transducer and activator of transcription 3 to induce epithelialmesenchymal transition in cancer cells via up-regulation of TWIST gene expression. Cancer Res 2007, 67:9066-9076

87. Fan C, He L, Kapoor A, Gillis A, Rybak AP, Cutz JC, Tang D: Bmil promotes prostate tumorigenesis via inhibiting p16(INK4A) and p14(ARF) expression. Biochim Biophys Acta 2008, 1782: 642-648

88. Rouet V, Bogorad RL, Kayser C, Kessal K, Genestie C, Bardier A, Grattan DR, Kelder B, Kopchick JJ, Kelly PA, Goffin V: Local prolactin is a target to prevent expansion of basal/stem cells in prostate tumors. Proc Natl Acad Sci U S A 2010, 107: 15199-15204 